\title{
The regime of aerosol asymmetry parameter over Europe, the Mediterranean and the Middle East based on MODIS satellite data: evaluation against surface AERONET measurements
}

\author{
M. B. Korras-Carraca ${ }^{1}$, N. Hatzianastassiou ${ }^{2}$, C. Matsoukas ${ }^{1}$, A. Gkikas ${ }^{3,2}$, and C. D. Papadimas ${ }^{2}$ \\ ${ }^{1}$ Department of Environment, University of the Aegean, 81100 Mytilene, Greece \\ ${ }^{2}$ Laboratory of Meteorology, Department of Physics, University of Ioannina, 45110 Ioannina, Greece \\ ${ }^{3}$ Earth Sciences Department, Barcelona Supercomputing Center, Barcelona, Spain
}

Correspondence to: N. Hatzianastassiou (nhatzian@cc.uoi.gr)

Received: 10 May 2014 - Published in Atmos. Chem. Phys. Discuss.: 5 September 2014

Revised: 11 September 2015 - Accepted: 1 October 2015 - Published: 26 November 2015

\begin{abstract}
Atmospheric particulates are a significant forcing agent for the radiative energy budget of the Earthatmosphere system. The particulates' interaction with radiation, which defines their climate effect, is strongly dependent on their optical properties. In the present work, we study one of the most important optical properties of aerosols, the asymmetry parameter $\left(g_{\text {aer }}\right)$, over sea surfaces of the region comprising North Africa, the Arabian Peninsula, Europe, and the Mediterranean Basin. These areas are of great interest, because of the variety of aerosol types they host, both anthropogenic and natural. Using satellite data from the collection 051 of MODIS (Moderate Resolution Imaging Spectroradiometer, Terra and Aqua), we investigate the spatiotemporal characteristics of the asymmetry parameter. We generally find significant spatial variability, with larger values over regions dominated by larger size particles, e.g., outside the Atlantic coasts of northwestern Africa, where desert-dust outflow takes place. The $g_{\text {aer }}$ values tend to decrease with increasing wavelength, especially over areas dominated by small particulates. The intra-annual variability is found to be small in desert-dust areas, with maximum values during summer, while in all other areas larger values are reported during the cold season and smaller during the warm. Significant intra-annual and inter-annual variability is observed around the Black Sea. However, the inter-annual trends of $g_{\text {aer }}$ are found to be generally small.

Although satellite data have the advantage of broad geographical coverage, they have to be validated against reliable surface measurements. Therefore, we compare satellite-
\end{abstract}

measured values with $g_{\text {aer }}$ values measured at 69 stations of the global surface AERONET (Aerosol Robotic Network), located within our region of interest. This way, we provide some insight on the quality and reliability of MODIS data. We report generally better agreement at the wavelength of $860 \mathrm{~nm}$ (correlation coefficient $R$ up to 0.47 ), while at all wavelengths the results of the comparison were better for spring and summer.

\section{Introduction}

Atmospheric aerosol particles interact with radiation, mainly the short wave (SW or solar) part of the spectrum, modifying the energy budget of the Earth-atmosphere system. The aerosol effect is either direct (through the scattering and absorption of solar radiation), thus reducing the incoming solar radiation flux at the surface, indirect (through the modification of cloud properties), or semi-direct (due to the absorption of solar radiation and consequent modification of the atmospheric temperature profile, convection, and cloud properties) (e.g., Graß1, 1979; Hansen et al., 1997; Lohmann and Feichter, 2005).

The interaction of particles with the solar flux, which defines their climate role, strongly depends on their optical properties (Hatzianastassiou et al., 2004, 2007), which cannot be covered globally by surface in situ measurements. Besides the aerosol optical depth (AOD), one of the most important optical properties of atmospheric particles, which is used 
in radiative transfer, climate, and general circulation models, is the asymmetry parameter $\left(g_{\text {aer }}\right)$. The asymmetry parameter describes the angular distribution of the scattered radiation and determines whether the particles scatter radiation preferentially to the front or back. The globally available satellitebased AOD data are considered to a great extent as reliable and adequate, due to significant developments in surface and satellite measurements during the last 2 decades, and particularly the arrival of MODIS in 2000, which is regarded as one of the most reliable data sets (Bréon et al., 2011; Nabat et al., 2013). On the other hand, despite the important role of the asymmetry parameter, relevant global coverage data are measured only for the few last years, or are available in longterm aerosol climatologies such as the Global Aerosol Data Set (GADS, Koepke et al., 1997) and Max Planck Aerosol Climatology (MAC, Kinne et al., 2013). Even so, asymmetry parameter data are usually examined for regions with limited geographical extent and temporal coverage (Di Iorio et al., 2003), without intercomparison between alternative data platforms.

The goal of the present work is the study of the spatiotemporal distribution of the aerosol asymmetry parameter, using the most recent data from MODIS (Moderate Resolution Imaging Spectroradiometer, collection 051). Emphasis is given to the comparison between the provided MODIS data and respective reliable surface measurements of the global AERONET, in order to gain insight on the quality of the former.

For this study we focus on the region defined by latitudes 5 to $70^{\circ} \mathrm{N}$ and longitudes $25^{\circ} \mathrm{W}$ to $60^{\circ} \mathrm{E}$, including North Africa, the Arabian Peninsula, Europe, and the greater Mediterranean Basin (Fig. 1). This area is selected because it is of particular scientific interest due to the simultaneous presence of a variety of particles, both natural and anthropogenic (e.g., desert dust, marine, biomass burning, anthropogenic urban/industrial pollution) as shown in previous studies (Lelieveld et al., 2002; Smirnov et al., 2002b; Sciare et al., 2003; Pace et al., 2006; Lyamani et al., 2006; Gerasopoulos et al., 2006; Engelstaedter et al., 2006; Satheesh et al., 2006; Kalivitis et al., 2007; Rahul et al., 2008; Kalapureddy et al., 2009; Alonso-Pérez et al., 2012; Zuluaga et al., 2012; Kischa et al., 2014) which makes this area ideal for aerosol studies. The presence of a variety of aerosols in the area is due to the fact that two of the largest deserts of the planet are partly included in our area of interest, i.e., the Arabian desert and the Sahara, while one finds also significant sources of anthropogenic pollution from urban and industrial centers, mainly in the European continent. Moreover, our area of interest and primarily its desert areas are characterized by a large aerosol load (large optical depth, Remer et al., 2008; Ginoux et al., 2012). In addition, significant regions in this area, more specifically the Mediterranean Basin and North Africa, are considered climatically sensitive, since they are threatened by desertification (IPCC, 2007, 2013). Finally, one more reason for the selection of study area is that

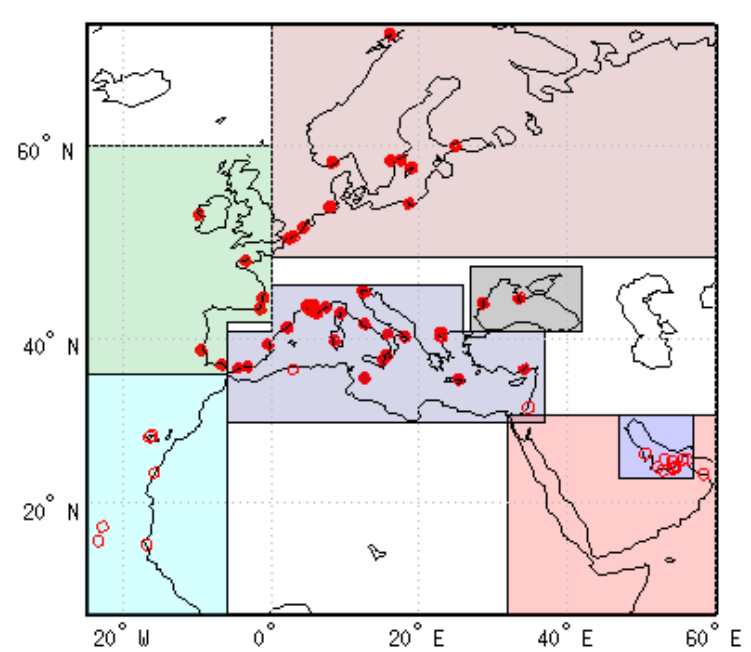

Figure 1. The study region $\left(5-70^{\circ} \mathrm{N}, 25^{\circ} \mathrm{W}-60^{\circ} \mathrm{E}\right)$ and the location of 69 AERONET stations used for validation of MODIS satellite aerosol asymmetry parameter $\left(g_{\text {aer }}\right)$ data. Solid red circles denote stations located in Europe and hollow red circles are stations in Africa, the Middle East and the Arabian Peninsula. Also shown are seven sub-regions selected for studying the seasonal variation of $g_{\text {aer. }}$.

the present study complements previous ones made by our team (e.g., Papadimas et al., 2008, 2012; Hatzianastassiou et al., 2009), analyzing other key aerosol optical properties, namely AOD for the same region. This is the first study (to our knowledge) that focuses on asymmetry parameter over a geographically extended area, while at the same time compares satellite with ground-station data.

\section{Data}

Before presenting the data used in this study, a short introduction of the parameter studied is given here for readers more or less unfamiliar with it. The asymmetry parameter (or factor) is defined by

$g=\frac{\bar{\omega}_{1}}{3}=\frac{1}{2} \int_{-1}^{1} P(\cos \Theta) \cos \Theta \mathrm{d} \cos \Theta$,

where $P$ is the phase function, which represents the angular distribution of the scattered energy as a function of the scattering angle $\Theta$ and it is defined for molecules, cloud particles, and aerosols. The phase function can be expressed using the Legendre polynomials $\bar{\omega}_{l}$ (see Liou, 2002) and $\bar{\omega}_{1}$ in Eq. (1) stands for $l=1$. The asymmetry parameter is the first moment of the phase function, and it is an important parameter in radiative transfer. For isotropic scattering, $g$ equals zero, which is the case for Rayleigh molecular scattering. The asymmetry parameter increases as the diffraction peak of the phase function sharpens. For Lorenz-Mie type parti- 
cles, namely for aerosols and cloud droplets, the asymmetry parameter takes positive values denoting a relative strength of forward scattering, with values increasing with particle size. It can also take negative values if the phase function peaks in backward directions $\left(90-180^{\circ}\right)$. The phase function and its simple expression, the asymmetry parameter, along with the extinction coefficient (or equivalently the optical depth) and the single scattering albedo, constitute the fundamental parameters that drive the transfer of diffuse intensity (Joseph et al., 1976) and are used in modeling. Hence, the importance of aerosol asymmetry parameter is easily understood for enabling computations of aerosol radiative properties and effects (e.g., forcings).

In this work, we use MODIS aerosol asymmetry parameter ( $\left.g_{\text {aer }}\right)$ data, which we compare with in situ measurements at AERONET stations. We provide a detailed description of the utilized data in the following sections.

\subsection{Satellite MODIS Terra and Aqua data}

MODIS is an instrument (radiometer) placed on the polarorbiting satellites of NASA (National Aeronautics and Space Administration) Terra and Aqua, $705 \mathrm{~km}$ from the Earth, in the framework of the Earth Observing System (EOS) program. Terra was launched on 18 December 1999, while Aqua was launched on 4 May 2002. The two satellites are moving on opposite directions, and their equatorial crossing times are at 10:30 (Terra) and 13:30 (Aqua). MODIS is recording data in 36 spectral channels between the visible and the thermal infrared $(0.44-15 \mu \mathrm{m})$, while its swath width is of the order of $2330 \mathrm{~km}$, which results in almost full planetary coverage on a daily basis.

Aerosol properties are monitored in seven spectral channels between 0.47 and $2.13 \mu \mathrm{m}$ and final results are derived through algorithms developed for aerosol quantities both over land and ocean (Kaufman et al., 1997; Tanré et al., 1997; Ichoku et al., 2002; Remer et al., 2005). MODIS data are organized in "collections" and "levels". Collections comprise data produced by similar versions of the inversion algorithms, with the recent collection "051" including also outputs from the "Deep Blue" algorithm. Levels are characterized by data of different quality analysis and spatial resolution.

In this study we use daily MODIS data for the asymmetry parameter $\left(g_{\text {aer }}\right)$ provided on an $1^{\circ} \times 1^{\circ}$ grid (namely $100 \mathrm{~km} \times 100 \mathrm{~km}$ ), from Collection 051, Level 3. These data were measured at wavelengths 470,660 , and $860 \mathrm{~nm}$, only over oceanic regions, since they were derived through the algorithm "Dark Target" over ocean. These wavelengths were selected in order to match as much as possible those of the available corresponding AERONET $g_{\text {aer }}$ product (see Sect. 2.2). The period of analysis stretches from 24 February 2000 to 22 September 2010 for MODIS-Terra and from 4 July 2002 to 18 September 2010 for MODIS-Aqua.
The MODIS C051 $g_{\text {aer }}$ data are a derived product of the MODIS algorithm over ocean. This MODIS algorithm (http: //modis.gsfc.nasa.gov/data/atbd/atbd_mod02.pdf, Remer et al., 2006) retrieves as primary products the AOD at $550 \mathrm{~nm}$, the fine-(mode) weighting ( $\mathrm{FW}$, also known as fraction of fine-mode aerosol type, FMF) and the Fine (f) and Coarse (c) modes used in the retrieval, along with the fitting error $(\varepsilon)$ of the simulated spectral reflectance. The algorithm reports additional derived parameters, such as the effective radius $\left(r_{\mathrm{e}}\right)$ of the combined size distribution, the spectral total, fine and coarse AODs or the columnar aerosol mass concentration. Among them, $g_{\text {aer }}$ is also derived and reported at seven wavelengths: 470, 550, 660, 860, 1200, 1600 and $2120 \mathrm{~nm}$. The derived parameters are calculated (Levy et al., 2013) from information contained within the look-up table (LUT) and/or other retrieved products. For example, knowing the resulting total AOD and FMF, and which aerosol types were selected (or assumed), one can go back to the LUT, and recover additional information about the retrieved aerosol, such as the $g_{\text {aer }}$. Hence, it should be noted that the derived $g_{\text {aer }}$ product is dependent on the used aerosol models (modes), since the algorithm is based on an LUT approach, assuming that one fine and one coarse lognormal aerosol modes can be combined with appropriate weightings to represent the ambient aerosol properties over the target (spectral reflectance from the LUT is compared with MODIS-measured spectral reflectance to find the "best" - least squares - fit, which is the solution to the inversion). In the C051 algorithm there are four fine modes and five coarse modes, for which the spectral (at the aforementioned seven wavelengths) aerosol asymmetry parameter values are given in Remer et al. (2006).

We also used Level 3 daily Ångström exponent data from MODIS-Aqua C051, and also spectral aerosol optical depth data from MODIS-Aqua C006 data sets, from which we computed C006 Ångström exponent. These data were used to assess the validity of $g_{\text {aer }}$ data and their temporal tendencies, as discussed in Sect. 3.2.3.

\subsection{Ground-based AERONET data}

AERONET (Aerosol Robotic Network) is a global network of stations focused on the study of aerosol properties. AERONET currently encompasses about 970 surface stations (number continuously evolving) equipped with sun photometers of type CIMEL Electronique 318 A (Holben et al., 1998), which take spectral radiation flux measurements.

The optical properties of aerosols are extracted through the application of inversion algorithms (Dubovik and King, 2000). Data are provided on three levels (1.0, 1.5, and 2). In the present work, we use the most reliable cloud-screened and quality-assured Level 2 data. AERONET calculates the asymmetry parameter at wavelengths $440,675,870$, and $1020 \mathrm{~nm}$. We employ daily Level 2 asymmetry parameter data from 69 stations (Fig. 1) contained in our study area (North Africa, the Arabian Peninsula, Europe). We choose 
only coastal stations in order to maximize the coexistence of satellite marine $g_{\text {aer }}$ data with surface data. Also, in order to compare corresponding data between the satellite and station platforms, we perform comparisons only for 440,675 , and $870 \mathrm{~nm}$.

\section{Satellite-based results}

\subsection{Geographical distributions}

The spatial distribution of annual mean values of $g_{\text {aer }}$ is given in Fig. 2 separately at the wavelengths 470, 660 and $860 \mathrm{~nm}$. The values are averages over the common period between Terra and Aqua, namely 4 July 2002 until 18 September 2010. A significant spatial variability is evident, with MODIS-Terra values varying within the ranges $0.63-0.76$, $0.57-0.75$, and $0.55-0.74$, at 470,660 and $860 \mathrm{~nm}$, respectively. The results exhibit a decreasing tendency of $g_{\text {aer }}$ with increasing wavelength, consistent with the theory. Similar results are also obtained from MODIS-Aqua, but with slightly smaller values than Terra by up to 0.02 on average. More specifically, the corresponding ranges of wavelengths are $0.63-0.75,0.57-0.73$, and $0.55-0.73$. The smaller Aqua than Terra $g_{\text {aer }}$ values could be attributed to smaller sizes of aerosols in midday than morning, corresponding to passages of Aqua and Terra, respectively, associated with lower relative humidity values and shrinking of aerosol particles. It should be reminded that the ability of atmospheric aerosol to absorb water affects the particle size (hygroscopic growth), as described by Köhler theory in the early 20th century. It is also well known that relative humidity significantly affects aerosol optical properties (e.g., Pilinis et al., 1996; Kondratyev, 1999), namely AOD, single scattering albedo and $g_{\text {aer }}$, by modifying the aerosol liquid water content, size and hence extinction coefficient and refractive indices.

In general, the largest $g_{\text {aer }}$ values (deep red colors) are observed off the coasts of West Africa (eastern tropical Atlantic Ocean) at all three wavelengths. High values are also found over the Red and Arabian seas. These high values are due to strong dust outflows from the Saharan and Arabian deserts carrying out coarse aerosol particles (Prospero et al., 2002; Alonso-Pérez et al., 2012; Miller et al., 2008) and causing strong forward scattering. Nevertheless, the Persian Gulf region, which is surrounded by deserts, is characterized by relatively smaller $g_{\text {aer }}$ values. More specifically, values as small as 0.69 (MODIS-Terra) and 0.67 (MODISAqua) are observed in this region at $470 \mathrm{~nm}$, while at the longer wavelengths $(660,860 \mathrm{~nm})$ the smallest values are equal to 0.66 (Terra) and 0.64 (Aqua). The smaller $g_{\text {aer }}$ values over the Persian Gulf can be attributed to the presence of fine aerosols, which is corroborated by the low effective radius and large fine-fraction measurements by MODIS over the Persian Gulf, compared to neighboring areas (not shown here). These fine particles originate from the industrial ac-
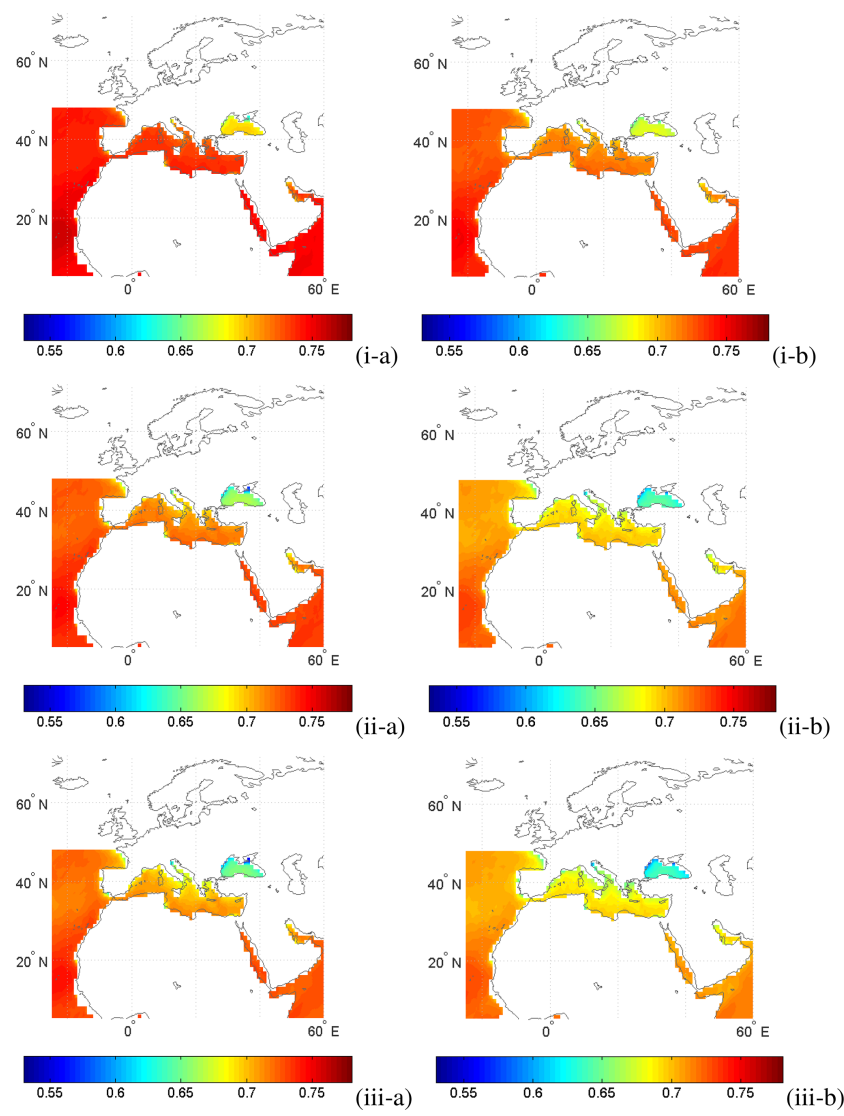

Figure 2. Geographical distribution of MODIS-Terra (-a, left column) and MODIS-Aqua (-b, right column) $g_{\text {aer }}$ values averaged over 2002-2010, at the wavelengths of $470 \mathrm{~nm}$ (i-, top row), $660 \mathrm{~nm}$ (ii-, middle row) and $860 \mathrm{~nm}$ (iii-, bottom row).

tivities in the Gulf countries related to oilfields or refineries (Goloub and Arino, 2000; Smirnov et al., 2002a, b; Dubovik et al., 2002).

The high $g_{\text {aer }}$ values over the northeastern tropical Atlantic Ocean as well as west of the Iberian coasts are possibly related with the presence of coarse sea salt particles. On the other hand, the asymmetry parameter takes clearly smaller values over the Black Sea, where according to MODIS-Terra, values vary between 0.63 and 0.7 at $470 \mathrm{~nm}, 0.57$ and 0.67 at $660 \mathrm{~nm}$, and 0.55 and 0.66 at $860 \mathrm{~nm}$, with the smallest values appearing over the Crimean Peninsula (corresponding maximum Aqua values are smaller by 0.02). The small Black Sea $g_{\text {aer }}$ values can be associated with industrial activities as well as biomass burning activities in nearby countries. A region of special interest is the Mediterranean Basin since it hosts a large variety of aerosols like anthropogenic, desert dust or sea salt (e.g., Barnaba and Gobbi, 2004). The MODIS results over this region show relatively small $g_{\text {aer }}$ values, secondary to those of the Black Sea, characterized by an increase from north to south, which is more evident at 660 and $860 \mathrm{~nm}$. More specifically, based on MODIS-Terra, $g_{\text {aer }}$ over 
the Mediterranean takes values from 0.68 to 0.74 at $470 \mathrm{~nm}$, while at 670 and $860 \mathrm{~nm}$ it ranges from 0.64 to 0.73 and 0.62 to 0.72 , respectively. According to MODIS-Aqua the $g_{\text {aer }}$ values are slightly smaller again. The observed low values in the northern parts of the Mediterranean are probably associated with the presence of fine anthropogenic aerosols transported from adjacent urban and industrial areas in the north, especially in central Europe. In contrast, the higher $g_{\text {aer }}$ values in the southern Mediterranean, particularly near the North African coasts, can be explained by the proximity to the Sahara desert and the frequent transport of significant amounts of coarse dust (e.g., Kalivitis et al., 2007; Hatzianastassiou et al., 2009; Gkikas et al., 2009, 2011, 2014).

The spatial distributions of climatological monthly mean $g_{\text {aer }}$ values from MODIS-Aqua at $470 \mathrm{~nm}$ reveal significant differences in the range and the patterns of the seasonal variability, depending on the area (Fig. 3). Thus, in tropical and sub-tropical areas of the Atlantic Ocean (up to about $30^{\circ} \mathrm{N}$ ), where dust is exported from the Sahara, $g_{\text {aer }}$ keeps high values throughout the year, which reach or even exceed 0.74 locally. Over the regions of Arabian and Red seas and the Gulf of Aden, which also experience desert dust transport, larger $g_{\text {aer }}$ values appear in the period from March to September, with a maximum in August (locally as high as 0.75-0.76). This seasonal behavior is in line with intra-annual changes of dust production over the Arabian Peninsula indicated by MODIS Ångström exponent (AE) and Deep Blue aerosol optical depth data (Ginoux et al., 2012), as well as over southwest Asia through in situ data (Rashki et al., 2012), aerosol index from various platforms and MODIS Deep Blue AOD data (Rashki et al., 2014). Indeed, the production of dust there is relatively poor in winter, increases in March and April and becomes maximum in June and July (Prospero et al., 2002). Over the Arabian Sea, it is known that large amounts of desert dust are carried out during spring and early summer (Prospero et al., 2002; Savoie et al., 1987; Tindale and Pease, 1999; Satheesh et al., 1999). Nevertheless, according to MODIS, the seasonal variability of $g_{\text {aer }}$ remains relatively small there in line with a small seasonal variability in MODIS Deep Blue AE data (results of our analysis, not shown here). This can be explained by the presence of sea salt coarse particles throughout the year, with which dust particles co-exist.

A greater seasonal variability exists over the Persian Gulf, where $g_{\text {aer }}$ values are higher during spring and in particular in summer (up to 0.74 at $470 \mathrm{~nm}$ according to Aqua), and lower in autumn and winter (area-minimum values smaller than 0.65). This seasonal behavior can be explained taking into account the meteorological conditions over the greater area of the Gulf; mainly in spring and summer, dry northwestern winds (Shamal) blow, carrying desert dust from the arid areas of Iraq (Smirnov et al., 2002a, b; Kutiel and Furman, 2003). The transport of dust is gradually decreased in autumn and reaches its minimum in winter. When the presence of desert dust is limited, a significant fraction of total

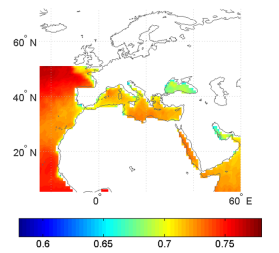

January

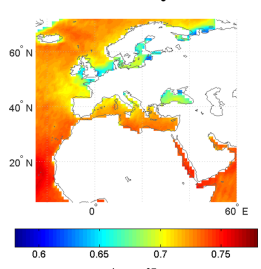

April

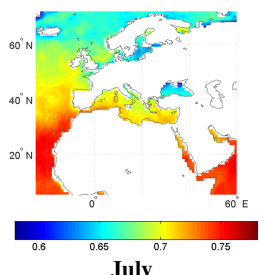

July

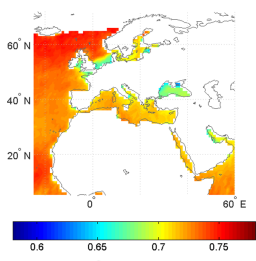

October

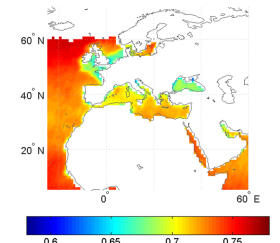

$\stackrel{0.65}{0.7}^{0.7}$

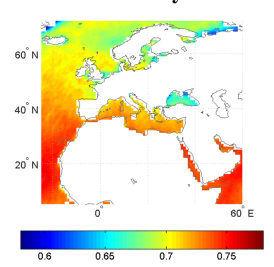

May

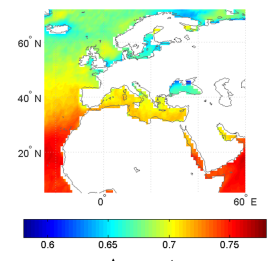

August

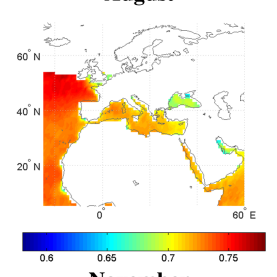

November

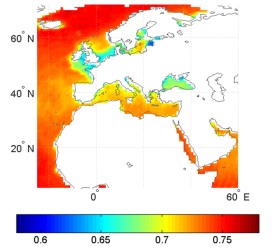

March

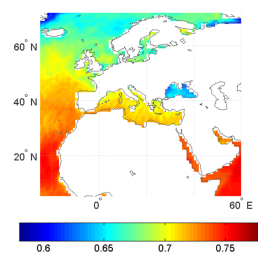

June

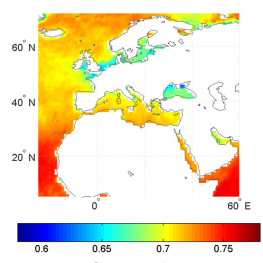

September

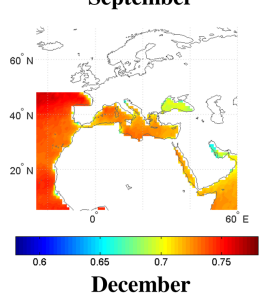

Figure 3. Month by month variation of MODIS-Aqua $g_{\text {aer }}$ values at $470 \mathrm{~nm}$ averaged over the period 2002-2010.

aerosol load in the region consists of fine anthropogenic particles (Smirnov et al., 2002a, b), which can explain the observed relatively small $g_{\text {aer }}$ values in autumn and winter.

In the Mediterranean Basin, $g_{\text {aer }}$ exhibits a relatively small seasonal variation, with lower values tending to appear in summer, in line with the presence of fine anthropogenic or biomass burning aerosols in the area, transported from the Balkans or central Europe (Hatzianastassiou et al., 2009). On the contrary, over the Black Sea, a clear seasonal cycle is apparent, with higher values in the cold period of the year and smaller in the warm one. More specifically, according to MODIS-Aqua, the values at $470 \mathrm{~nm}$ drop down to 0.61 in summer months whereas they reach 0.7 in January and December. This seasonality is in agreement with the summer biomass burning from agricultural activities and wildfires (Barnaba et al., 2011; Bovchaliuk et al., 2013), and the resulting abundance of fine particles.

It is also interesting to look at the geographical distribution of monthly $g_{\text {aer }}$ values in latitudes higher than $50^{\circ} \mathrm{N}$, for which annual mean values were not given in Fig. 2 because of unavailability of data for all months. Off-shore northern France (English Channel) and Germany the asymmetry pa- 
rameter has small seasonally constant values (note that data do not exist for January and February). In these areas, the aerosol load consists mainly of anthropogenic polluted particles, which explains the small $g_{\text {aer }}$ values.

In the Baltic Sea (values available from March to October) $g_{\text {aer }}$ shows a significant spatial and temporal variability. More specifically, it is small during summer, whereas it increases, locally up to more than 0.7, in March and October. The smaller summer values can be explained by the presence of fine aerosols in the Baltic Sea originating from forest fires in Europe and Russia (Zdun et al., 2011). On the contrary, in autumn the local aerosol loading consists largely of coarse marine aerosols. It is also important to note that the Baltic Sea hosts significant amounts of anthropogenic industrial and urban aerosols throughout the year, but especially in summer (Zdun et al., 2011).

In the higher latitudes of Atlantic Ocean, where the presence of maritime aerosols is dominant, we note a remarkable month by month variation of asymmetry parameter, with low values in summer (values up to 0.59) against high values (up to $0.75-0.77$ ) in spring (March, April) and autumn (October). This difference is possibly explained by the seasonal variability of aerosol size in the northern Atlantic. Apart from the presence of coarse sea salt throughout the year, in spring and summer small particles are formed through photochemical reactions of dimethylsulfide (DMS) emitted by phytoplankton decreasing the aerosol size. Moreover during summer fine anthropogenic aerosols are transported in the region from North America (Yu, 2003; Chubarova, 2009). These re-

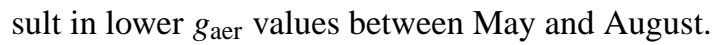

Based on MODIS-Terra, the patterns of spatial distribution are generally the same with Aqua, with slightly larger $g_{\text {aer }}$ values. At larger wavelengths $(660,860 \mathrm{~nm})$ a decrease of $g_{\text {aer }}$ is observed, especially for its smallest values. Further details and an overall picture are given in Sect. 3.2.1 which deals with climatological monthly mean values not at the pixel but at the regional level.

\subsection{Temporal variability}

\subsubsection{Seasonal variability}

In order to provide an easier assessment of the seasonal cycle of aerosol asymmetry parameter and its changes from one region to another, but also among the different wavelengths (470, 660 and $860 \mathrm{~nm}$ ), the study region was divided into seven smaller sub-regions (see Fig. 1). The average values of monthly mean climatological (2002-2010) data of the pixels found within each sub-region's geographical limits have been computed and are given in Fig. 4, for every wavelength, both for Terra and Aqua. It appears that the seasonal cycle differs between the sub-regions, as it has already been shown in the geographical map distributions discussed in the previous section.
At $470 \mathrm{~nm}$ (Fig. 4i), the intra-annual variability of $g_{\text {aer }}$ is greater over the Black Sea, where it is as large as 0.06 according to MODIS-Terra and 0.05 according to MODIS-Aqua, the northeastern Atlantic Ocean $(0.04$ and 0.05 for Terra and Aqua, respectively) and the seas of northern Europe ( 0.05 for both Terra and Aqua). In these regions, there is a tendency for smaller values during summer. More specifically, in the Black Sea the smallest $g_{\text {aer }}$ value (0.64) is observed in June, over the seas of northern Europe in July and over the northeastern Atlantic Ocean in August. In these regions, the largest values appear in the cold period of the year. Reverse seasonality with a large seasonal amplitude is observed over the Persian Gulf, where the variability is as large as 0.08 , according to both MODIS-Terra and MODIS-Aqua. The seasonal cycle of $g_{\text {aer }}$ over the Middle East exhibits a smaller range of variability (0.02 for MODIS-Terra and 0.03 for Aqua), with maximum values in summer and minimum in winter. In the other two sub-regions (Mediterranean and eastern Atlantic Ocean) the annual range of values is small $(<0.02)$. It is noteworthy that in the Mediterranean Sea, there is a weak tendency of appearance of double maxima in winter and spring. The spring maximum should be associated with the presence of desert dust particles, which are transported from Sahara, mainly in the eastern Mediterranean in this season (e.g., Fotiadi et al., 2006; Kalivitis et al., 2007; Papadimas et al., 2008, Gkikas et al., 2009, 2013; Hatzianastassiou et al., 2009). There is also a similar transport of Saharan dust in the central and western Mediterranean during summer and autumn (e.g., Gkikas et al., 2009, 2013), but then the predominance is not so clear because of the co-existence of fine anthropogenic aerosols. Regardless of the annual cycle, smaller $g_{\text {aer }}$ values are clearly distinguished over the Black Sea and northern European seas throughout the whole year.

At $660 \mathrm{~nm}$, the $g_{\text {aer }}$ values are lower than at $470 \mathrm{~nm}$, in particular over the Black Sea, northern Europe and the northeastern Atlantic, whereas the intra-annual variability (range

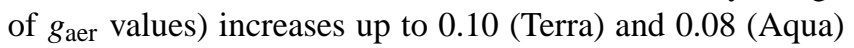
over the Black Sea. This increase is mainly attributed to the reduction of summer values due to the strong appearance of fine aerosols in this season. Also, at $660 \mathrm{~nm}$, there is a clearer double annual variation of $g_{\text {aer }}$ over the Mediterranean Sea than at $470 \mathrm{~nm}$. At $860 \mathrm{~nm}$ the general picture is similar to that of $660 \mathrm{~nm}$ though a further increase of month by month variability is noticeable.

In general, our results indicate that over the regions characterized by a strong presence of desert dust particles (eastern Atlantic and the Middle East and the Mediterranean Sea) the annual range of variability of $g_{\text {aer }}$ is smaller than in the other regions. An additional feature above regions with desert dust is the smaller decrease of $g_{\text {aer values with increas- }}$ ing wavelengths. This is attributed to the lower $g_{\text {aer }}$ spectral dependence of coarse compared to fine particles (e.g., Dubovik et al., 2002; Jianrong et al., 2011). 

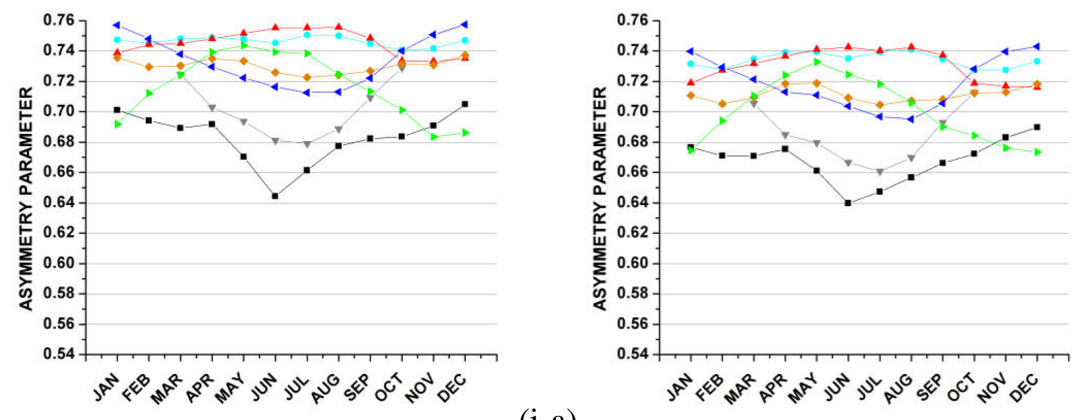

(i-a)

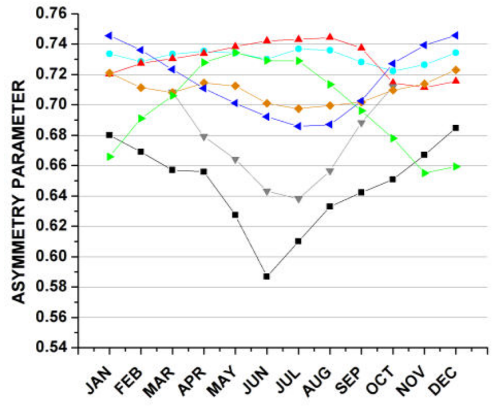

(ii-a)

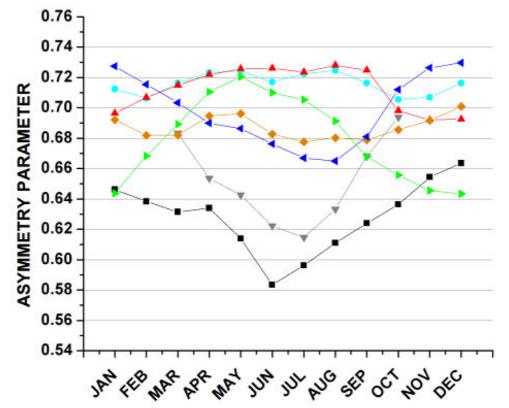

(ii-b)

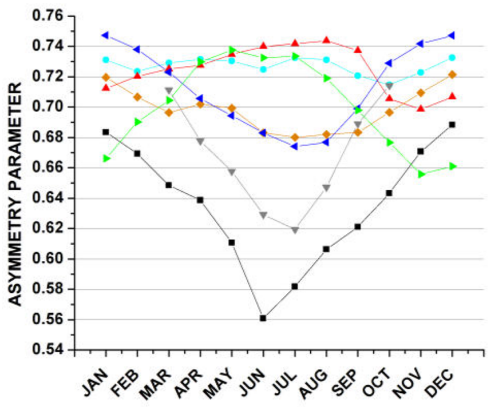

(iii-a)

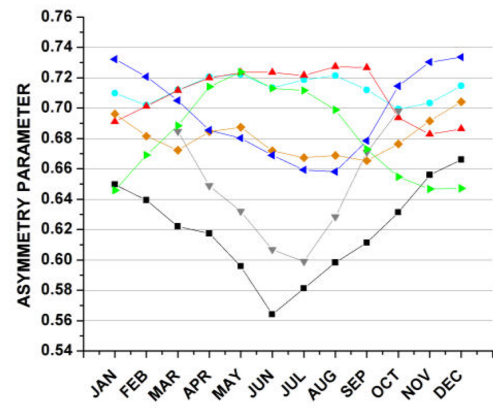

(iii-b)

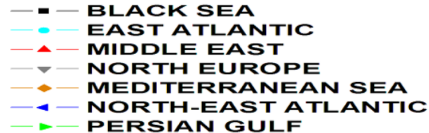

Figure 4. Intra-annual variation of MODIS, Terra (-a, left column) and Aqua (-b, right column), $g_{\text {aer }}$ values averaged over seven selected

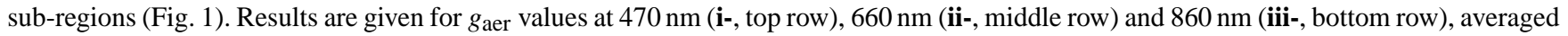
over the period 2002-2010, respectively.

We should note that the MODIS-Terra and Aqua $g_{\text {aer }}$ seasonal cycles are about similar but with generally greater Terra than Aqua values.

\subsubsection{Inter-annual variability and changes}

Figure 5 displays the geographical distribution of the slope of inter-annual trend of $g_{\text {aer }}$ over the study region, as computed from the application of the Mann-Kendall test to time series of de-seasonalized monthly anomalies of $g_{\text {aer }}$ at $470 \mathrm{~nm}$. Results are shown in units decade ${ }^{-1}$ for both Terra and Aqua over their common time period, namely 2002-2010, only if the trend is statistically significant at the $95 \%$ confidence level. We also performed the same analysis for the 660 and $860 \mathrm{~nm}$ (not shown), with similar results to the $470 \mathrm{~nm}$ wavelength.

In general, the estimated changes are relatively small. Terra produces widely statistically significant positive trends, showing that during the period of interest, the asymmetry parameter increased over the examined area, with very few exceptions. The results from Aqua are statistically significant at considerably fewer cells, while they give a few points 

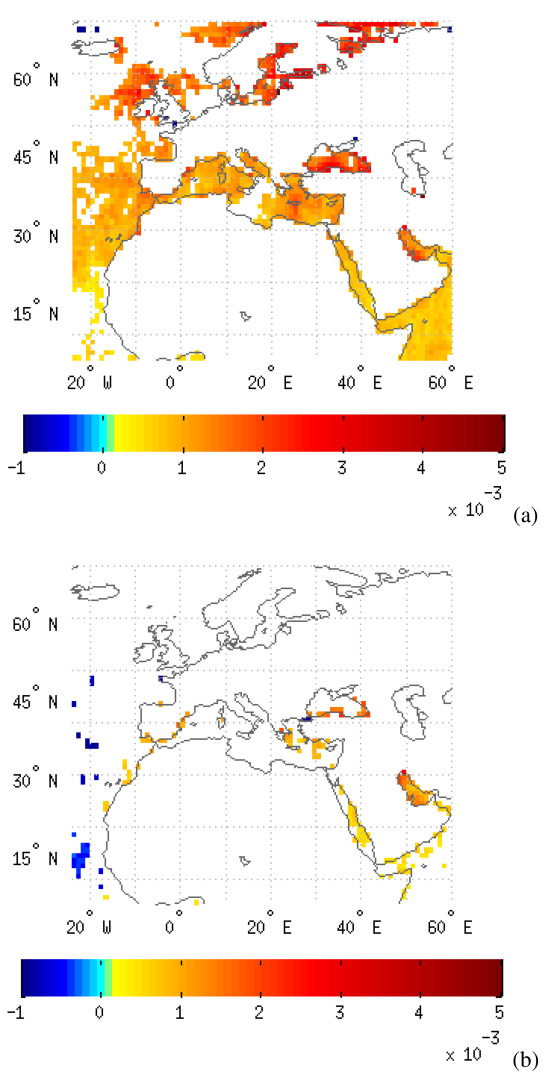

Figure 5. Slope (in units decade ${ }^{-1}$ ) of MODIS $g_{\text {aer }}$ deseasonalized anomalies over the period 2002-2010 from MODISTerra (-a, top) and MODIS-Aqua (-b, bottom), for the wavelengths of $470 \mathrm{~nm}$. Results are shown only if the trend is statistically significant at the $95 \%$ confidence level.

with decreasing $g_{\text {aer. }}$ Based on Terra data, the stronger increases are observed in the eastern and southern Black Sea, as well as over the Baltic and Barents seas. According to MODIS-Aqua, negative trends are found over few Atlantic Ocean cells. Both Aqua and Terra report increases of $g_{\text {aer }}$ over the Persian Gulf, the Red Sea, southern Black Sea, the eastern Mediterranean Sea, the coast of the Iberian Peninsula, and some coastal areas of West Africa. The differences encountered between the Terra and Aqua $g_{\text {aer }}$ trends may be attributed to the different time of passage of each satellite platform carrying the same MODIS instrument, given that everything else is the same. Nevertheless, they may more probably be the result of calibration differences between the two MODIS sensors. It is known that there is a degradation of MODIS sensor (Levy et al., 2010; Lyapustin et al., 2014) impacting time series of MODIS products. More specifically, it is also known that Terra suffers more than Aqua from optical sensor degradation. These calibration issues are known to affect MODIS AOD retrievals, producing an offset between Terra and Aqua, and they are also expected to affect the aerosol asymmetry parameter, which is probably more sensitive to such calibration uncertainties than AOD. In this sense, the results of Fig. 5 shown here are not to be taken as truth but rather they are given as a diagnostic of a problematic situation with MODIS aerosol asymmetry parameter inter-annual changes. Such calibration issues are expected to be addressed, at least partly, in the new Collection 006 products. Nevertheless, a preliminary comparison between MODIS Aqua C051 and C006 Ångström exponent (AE), which is another common aerosol parameter strongly dependent on size, using data for the $550-865 \mathrm{~nm}$ pair of wavelengths spanning the period 2002-2010, does not reveal significant modifications in geographical patterns of AE interannual changes. This puts some confidence on the C051 $g_{\text {aer }}$ results given in the present study. The results of this analysis are presented in detail in the next Sect. 3.2.3.

The overall $g_{\text {aer }}$ changes of Fig. 5 may hide smaller timescale variations of $g_{\text {aer }}$, which are obtained by the timeseries shown in Fig. 6. Results are given for the seven subregions defined previously, at the three different wavelengths and for Terra and Aqua separately. A general pattern is the decrease of $g_{\text {aer }}$ values with increasing wavelength, in particular from 470 to $660 \mathrm{~nm}$. The largest month-to-month and year-to-year variation is for the Black Sea (Fig. 6i). Relatively large variability is also found in the sub-regions of NE Atlantic (6v), northern Europe (6vi) and the Persian Gulf (6vii). On the contrary, small variability is noticed in the eastern Atlantic, where systematic dust outflows from Sahara take place, leading to consistently high values of $g_{\text {aer }}$. There are also some other interesting patterns, like the significant drop of $g_{\text {aer }}$ with wavelength in areas characterized by the presence of fine aerosols, namely the Black Sea, northern Europe and the Persian Gulf (Fig. 6i, vi, vii, respectively). The specific patterns of inter-annual changes of $g_{\text {aer }}$ are suggested by both Terra and Aqua, though a slight overestimation by Terra is again apparent in this figure. The obtained results of our analysis are meaningful and in accordance with the theory, underlining the ability of satellite observations to reasonably capture the $g_{\text {aer }}$ regime over the studied regions.

\subsubsection{Possible uncertainties of MODIS aerosol asymmetry parameter}

The MODIS aerosol asymmetry parameter is not a direct product of the MODIS retrieval algorithm, but it is rather a derived by-product. Since this parameter is dependent on aerosol modes used and relative weights (see Sect. 2.1), it is understood that there can be uncertainties associated with it. Therefore questions may arise about the validity of $g_{\text {aer }}$ and their spatial and temporal patterns presented in the previous sub-sections. Given that, as already mentioned, it is an aerosol optical parameter that is valuable and highly required by radiative transfer and climate models, it is worth assessing it through comparison against another more common aerosol size parameter, namely the C051 MODIS Ångström exponent at the $550-865 \mathrm{~nm}$ wavelength pair $\left(\mathrm{AE}_{550-865}\right)$ over ocean, which is an evaluated MODIS aerosol size product 

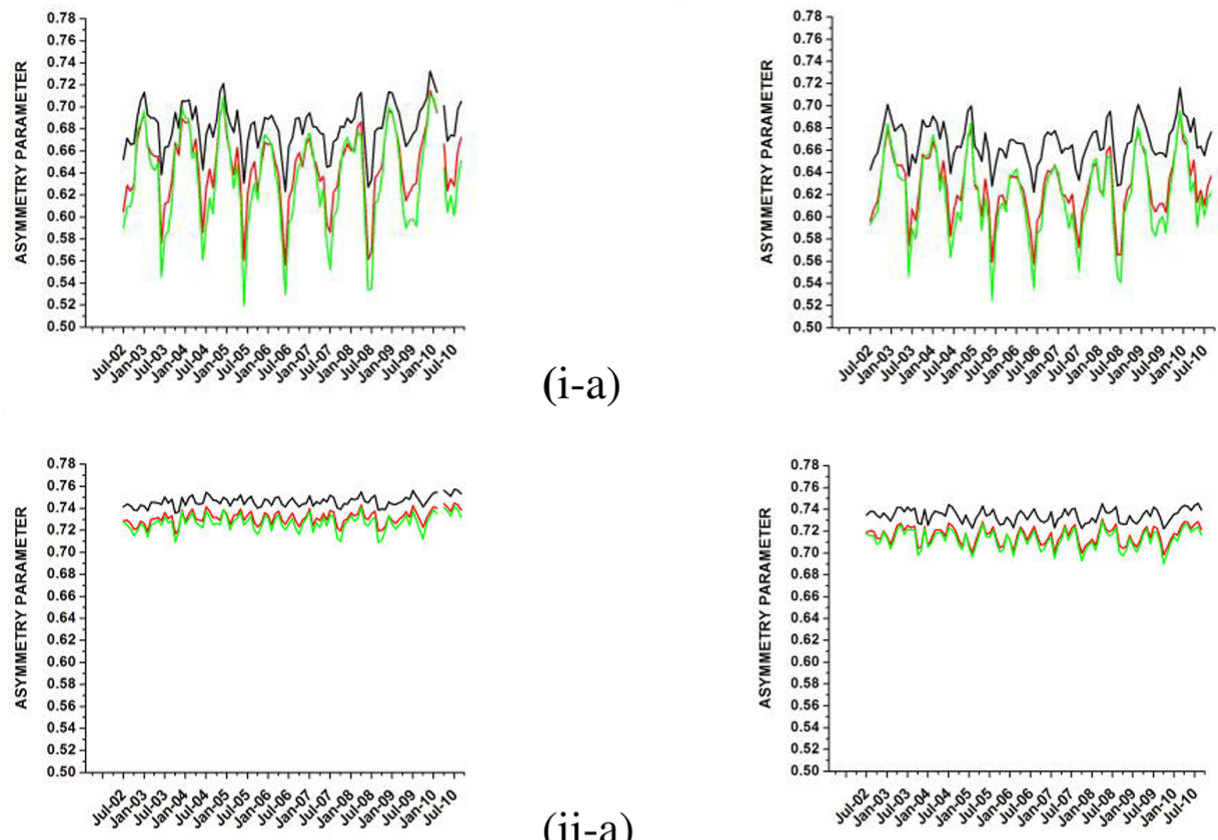

(ii-b)
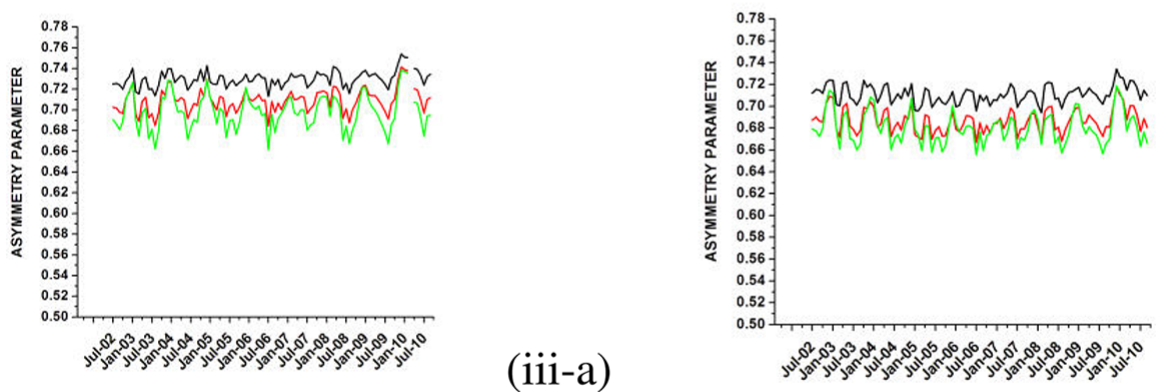

(iii-b)
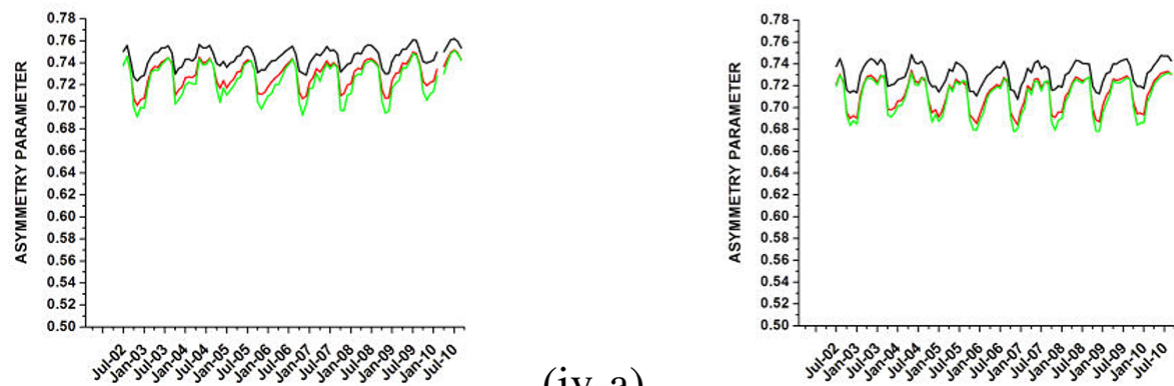

(iv-b)

Figure 6.

(Levy et al., 2010) that is extensively used in literature. Figure $7 \mathrm{a}$, displays the geographical distribution of long-term average $\mathrm{AE}$ for the whole study period, i.e., 2002-2010. In this figure, the northernmost areas are blank because there are no data during winter and a long-term average would be biased. The main geographical patterns in Fig. 7a are in line with those of asymmetry parameter (Fig. 2). For example, note the high AE values in the Black Sea (between about 1.3 and 1.8, yellowish-reddish colors), indicative of fine aerosols, the relatively high values in the Mediterranean Sea (between about 0.7 and 1.2, greenish-yellowish colors) and the low values (0.1-0.4, deep bluish colors) off the western African coasts corresponding to exported Saharan dust. Over the same areas, $g_{\text {aer }}$ takes inverse low and high values, for example smaller than 0.65 over the Black Sea and larger than $0.7-0.75$ off the western African coasts (Fig. 2ii$\mathrm{b}$ and iii-b), indicating the predominance of fine and coarse aerosols respectively, in accordance with AE. The consis- 

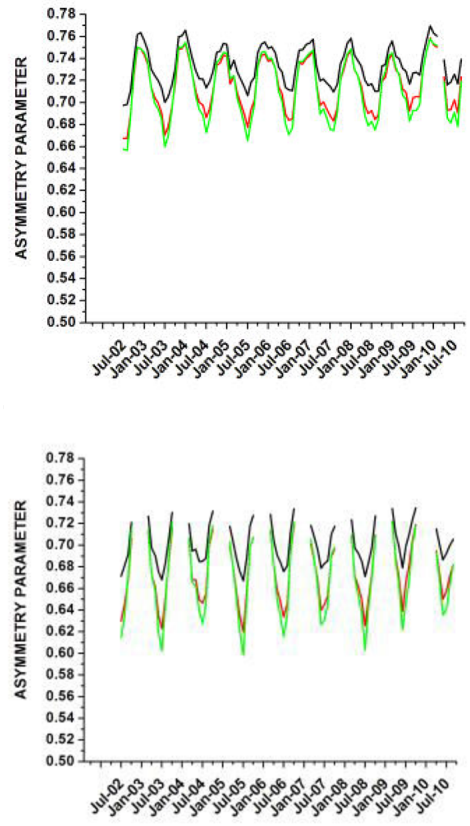

(vi-a)

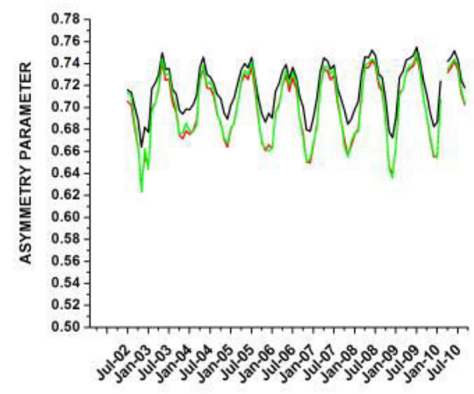

(vii-a)

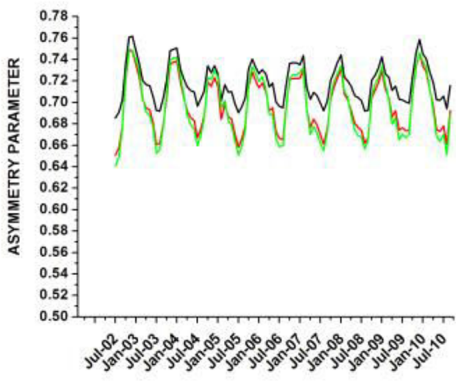

$(\mathrm{v}-\mathrm{b})$

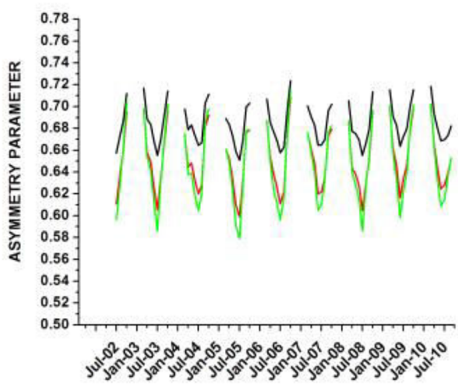

(vi-b)

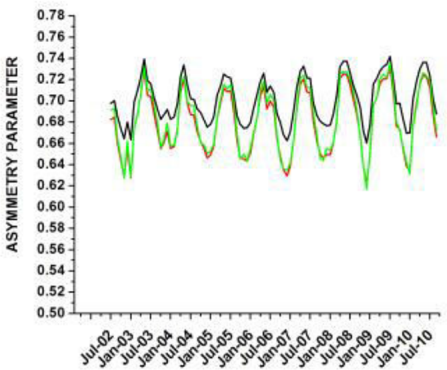

(vii-b)

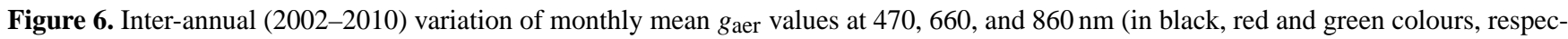
tively), over the sub-regions of (i) Black Sea, (ii) eastern Atlantic Ocean, (iii) Mediterranean Sea, (iv) Middle East, (v) northeastern Atlantic Ocean, (vi) northern Europe and (vii) Persian Gulf. Results are given based on MODIS-Terra (-a, left column) and MODIS-Aqua (-b, right column).

tency between $g_{\text {aer }}$ and AE data is shown by the strong anticorrelation between the MODIS AE $550-865$ and $g_{\text {aer }}$ data at 660 and $860 \mathrm{~nm}$, shown in Fig. 7b and c, respectively. It should be noted that correlation coefficients are computed from any available data pairs, i.e., available data for both $g_{\text {aer }}$ and $\mathrm{AE}_{550-865}$ at a given pixel and day. Note that there are no blank areas in Fig. 7b and c, in contrast to Fig. 7a. There are both $\mathrm{AE}$ and $g_{\text {aer }}$ data for all seasons except winter; therefore, correlation coefficients can be calculated for these regions. Strong negative correlation coefficients, larger than 0.7 and 0.8 in Fig. 7b and c, respectively, relate inversely high $g_{\text {aer }}$ values with low $\mathrm{AE}$ ones and vice-versa, over the same areas. In both cases (Fig. 7b and c), the correlation is slightly higher over sea areas characterized by the presence of fine aerosols (e.g., the Black Sea or the Persian Gulf) and lower over seas undergoing frequent transport of coarse dust particles (e.g., southern Mediterranean Sea, Arabian Sea, or Atlantic Ocean off the western African coasts). The overall computed correlation coefficient between $g_{\text {aer }}$ and $\mathrm{AE}$ is equal to -0.95 over the Black Sea, -0.89 over the Mediterranean Sea, -0.87 and -0.94 over the Arabian Sea and Persian Gulf, respectively and -0.89 off the western African coasts (values given for AE $550-865$ and $g_{\text {aer }}$ data at $860 \mathrm{~nm}$ ). These results indicate that the spatial patterns of MODIS C051 $g_{\text {aer }}$ product are reasonable as compared to the C051 Ångström exponent data. This shows that the use of $g_{\text {aer }}$ in modeling studies can be considered as reasonably reliable with regards to the consideration of fine and coarse aerosols over the examined study area, with slightly more confidence over areas characterized by the presence of fine particles, such as the Black Sea or Persian Gulf.

Since questions may also arise about possible uncertainties regarding the long-term variability of MODIS C051 aerosol size products, due to the calibration issues discussed in the 


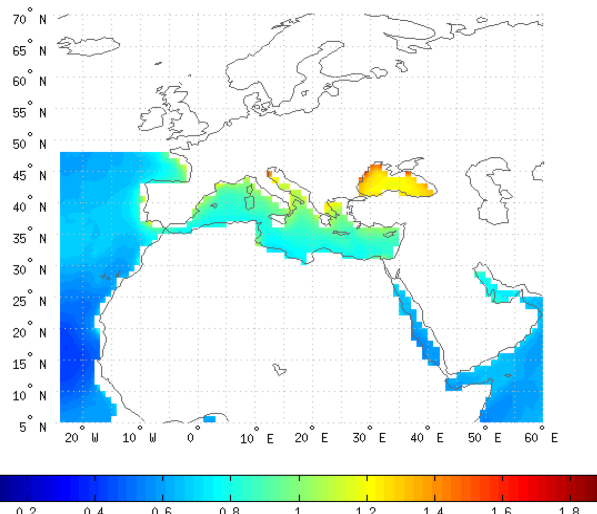

(a)

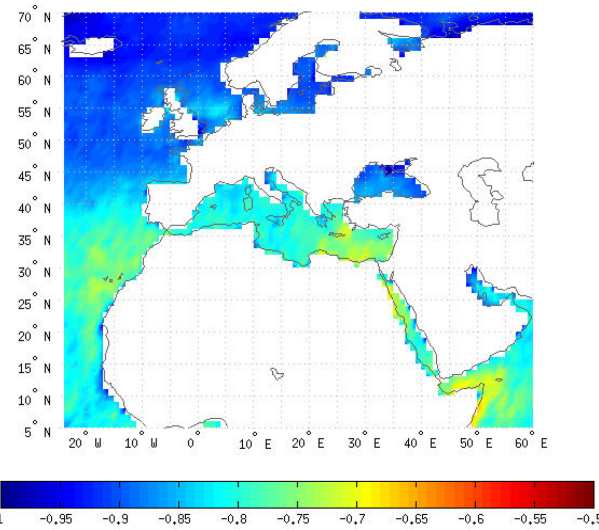

(b)

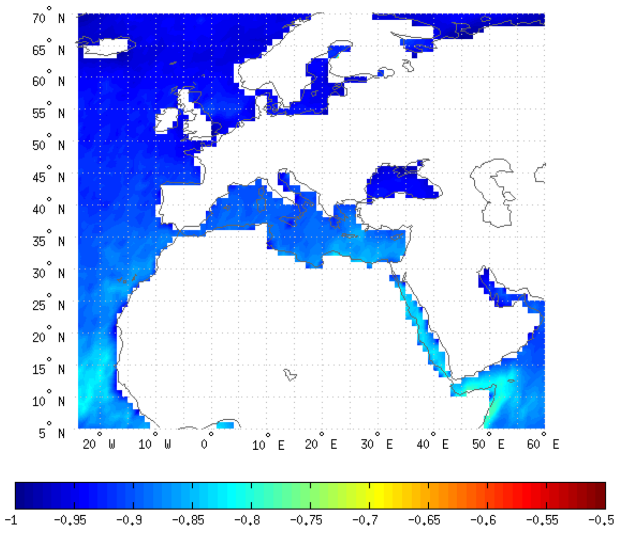

(c)

Figure 7. (a) Geographical distribution of MODIS-Aqua 051 Ångström exponent (AE $550-865)$ values averaged over 2002-2010, at the wavelength pair of $550-865 \mathrm{~nm}$. Winter AE data are missing from the northernmost areas, and therefore the long-term averages in (a) are left blank. The correlation coefficients between $\mathrm{AE}_{550-865}$ and $g_{\text {aer }}$ data at 660 and $860 \mathrm{~nm}$ are given in (b) and (c), respectively.

previous section, the corresponding MODIS C006 AE product is displayed in Fig. 8a. Figures 8a and 7a are similar in the main geographical patterns of the two collections' AE product. The similarity between C051 and C006 AE data is also depicted in the computed correlation coefficients (Fig. 8b), exceeding 0.8 , and biases (in absolute and relative percentage terms, Fig. $8 \mathrm{c}$ and d, respectively). For the Mediterranean Sea, the Arabian Sea and Persian Gulf, biases are smaller than 0.1 or $10 \%$ in most areas and 0.2 or $20 \%$ almost everywhere. Relative biases larger than $30 \%$ are only observed over the open Atlantic Ocean. The overall computed correlation coefficient for the entire study region is $0.88(0.86,0.89$, 0.95 and 0.84 for Mediterranean, Arabian, Persian and Atlantic sea surfaces off the western African coasts). The corresponding overall relative percent bias is equal to $15.6 \%$ (9.1, 6.7, 6.1 and 15.7 for the same sub-areas as above). Our results indicate that the uncertainty related to the use of C051 AE data is small, especially over the Mediterranean Sea, the Arabian Sea, the Persian Gulf and the Atlantic Ocean areas not far from the European, African and Asian coastlines. Our AE results are in line with those of Levy et al. (2013, Fig. 15) which refer, however, only to 2008 (ours are for 2002-2010). In addition, a comparison is attempted in Fig. 8e and $\mathrm{f}$ between the computed trends of C051 and C006 AE data over the common period 2002-2010, in order to assess whether changes are detected, which could be an indication of possible changes in corresponding asymmetry parameter trends. Figure $8 \mathrm{e}$ and $\mathrm{f}$ show the computed de-seasonalized trends of slope values for both $\mathrm{C} 051$ and $\mathrm{C} 006 \mathrm{AE}$. The results reveal similar patterns between $\mathrm{C} 051$ and C006. Small trends are found in both of them, in agreement with the small trends of asymmetry parameter reported in Fig. 5 . We find that the sign of AE trends basically does not change from C051 to C006. This might be a signal that no changes of aerosol asymmetry parameter are expected in $\mathrm{C006}$ and puts confidence on the $\mathrm{C} 051 g_{\text {aer }}$ results given in the present study.

\section{Evaluation against AERONET data}

In order to evaluate the satellite-measured aerosol asymmetry parameter, we identified the AERONET stations inside our area of interest and finally utilized only the coastal ones, so that both satellite and surface data be available. The total number of these stations is 69 , and their locations are shown in Fig. 1 (open and full circles).

Table 1 contains the comparison statistical metrics for all wavelengths (Pearson correlation coefficient, bias, root mean square error (RMSE), slope, intercept) of the comparison between surface daily mean data from AERONET and satellite data from MODIS-Terra and MODIS-Aqua, which correspond to the $1^{\circ} \times 1^{\circ}$ cell wherein each station is located. For this analysis, we use all cells and days with common data between Terra-AERONET and Aqua-AERONET. The mean differences are calculated as $g_{\text {aer }}$ (AERONET)$g_{\text {aer }}$ (Aqua) and $g_{\text {aer }}$ (AERONET) $-g_{\text {aer }}($ Terra)

In general, we may note that on an annual level, the MODIS-Terra and Aqua asymmetry parameter values at $470 \mathrm{~nm}$ are not in very good agreement with the respective 

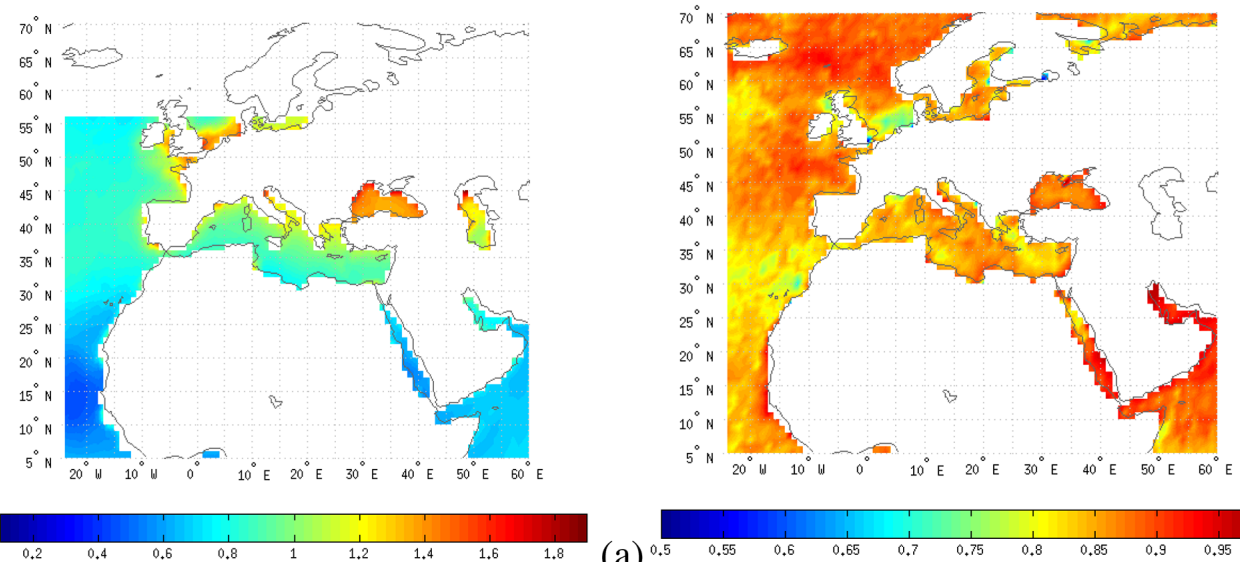

(a)
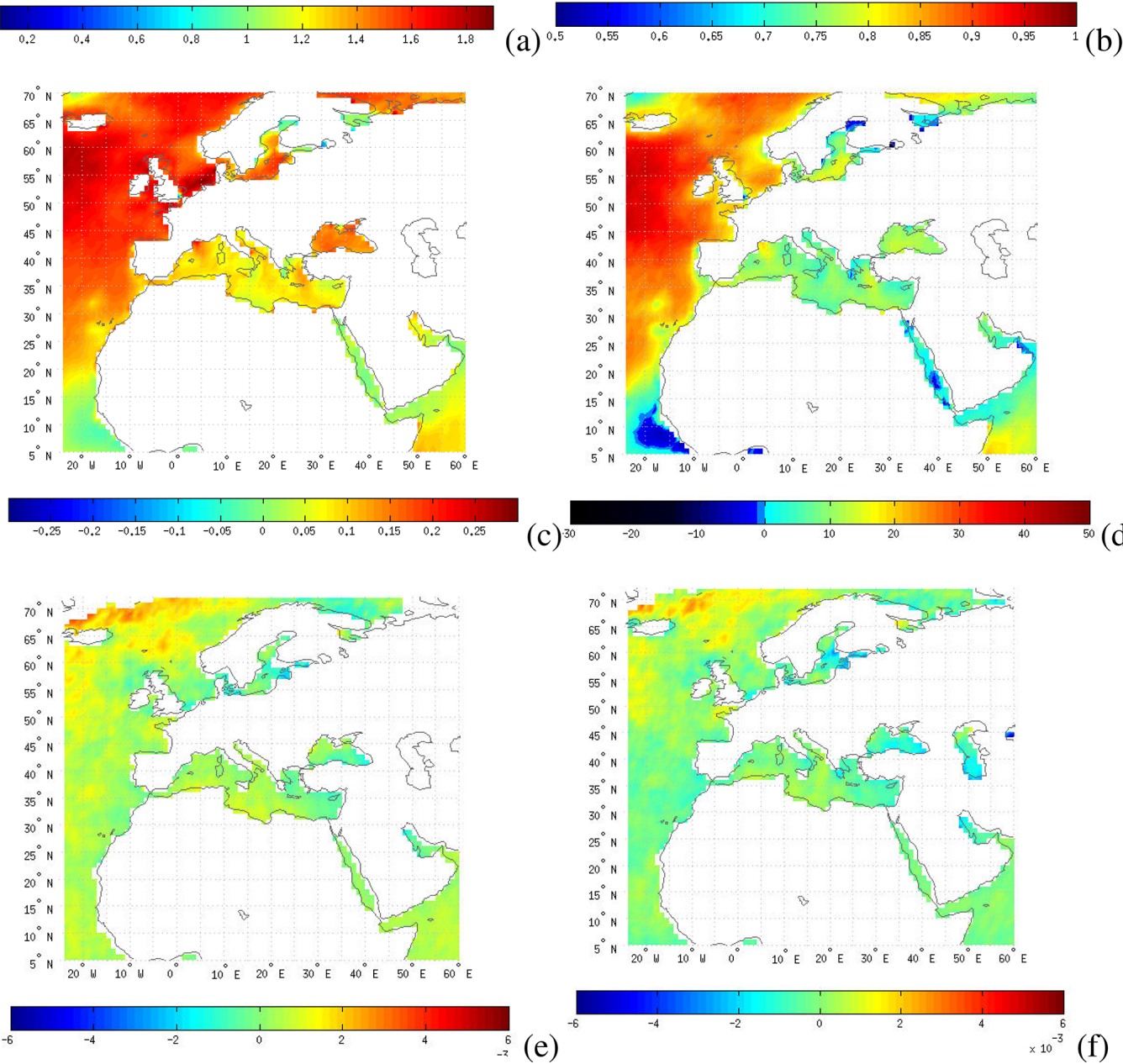

Figure 8. (a) Geographical distribution of MODIS-Aqua C006 Ångström exponent (AE $550-865)$ values averaged over 2002-2010, at the wavelength pair of 550-865 nm. Winter AE data are missing from the northernmost areas, and therefore the long-term averages in (a) are left blank. In (b), (c) and (d) are given the correlation coefficients, the absolute biases and the relative percent biases, respectively, between the C006 and corresponding $051 \mathrm{AE}_{550-865}$ data. In (e) and (f) are given the computed de-seasonalized trends of MODIS Aqua 051 and C006 $\mathrm{AE}_{550-865}$ ) slope values for years 2002-2010, respectively.

data from AERONET at $440 \mathrm{~nm}$. Results at larger wavelengths are more reassuring, although still not very satisfactory. We note that R, RMSE and slope generally increase with wavelength. At 870/860 nm (Table 1 and Fig. 9), cor- relation coefficients are found to be the largest and equal to 0.47 (AERONET-Terra) and 0.46 (AERONET-Aqua), while satellite data are slightly overestimated compared to the sur- 


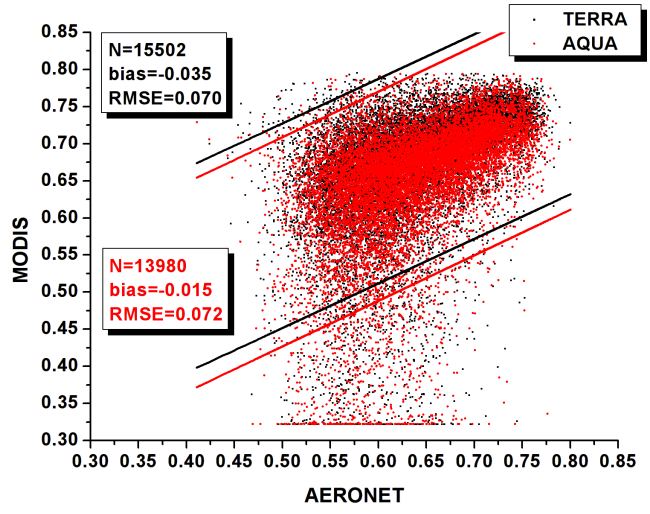

Figure 9. Scatterplot comparison between $g_{\text {aer }}$ values at $860 \mathrm{~nm}$ from MODIS Terra (black color) and Aqua (red color) and corresponding values from AERONET stations at $870 \mathrm{~nm}$ (blue squares, Fig. 1). The $95 \%$ prediction bands as well as the mean bias (AERONET minus MODIS) and root mean squared error are given.

face data (bias -0.035 or $5.54 \%$ and -0.015 or $-2.43 \%$, respectively).

It is interesting that the correlation coefficient and slope between satellite and surface data is better in spring and summer, for all studied wavelengths. On the other hand, winter is generally the season with the largest bias, while RMSE seems insensitive to the season.

Moreover, we find that for all seasons $g_{\text {aer }}$ values at 860 and $660 \mathrm{~nm}$, both from MODIS-Terra and MODISAqua, are overestimated compared to $g_{\text {aer }}$ (AERONET) at the corresponding wavelengths (stronger overestimation at $860 \mathrm{~nm}$ and by Terra). Finally we note an underestimation of $g_{\text {aer }}$ at $470 \mathrm{~nm}$ from MODIS-Aqua, relative to the data by AERONET at $440 \mathrm{~nm}$, while very small biases $(<0.5 \%)$ are found between Terra and AERONET at the same wavelengths.

In Fig. 9 we present a scatterplot comparison between MODIS and AERONET $g_{\text {aer }}$ data pairs. There is bias towards larger $g_{\text {aer }}$ values from both Aqua and Terra compared to AERONET, with Terra overpredicting more than Aqua. The root mean square error to the fit between MODIS and AERONET is very similar between Aqua and Terra. There are concerns on the application of ordinary least squares regression, arising from the assumption that as the assigned independent variable, AERONET values should be free from error. We cannot guarantee the validity of this assumption, so we recognize that the reported $R$ and slope values from Fig. 9 and Table 1, if viewed as metrics of agreement between MODIS $g_{\text {aer }}$ and real $g$, may be subject to the effect of regression dilution and consequently biased low. This possible bias for $R$ and slope could be neglected only if AERONET errors can also be considered negligible. With the above caveat in mind, the applied least-squares fit line to the scatterplot comparison between matched MODIS-AERONET data pairs (Fig. 9) indicates that MODIS overestimates $g_{\text {aer }}$ more in the

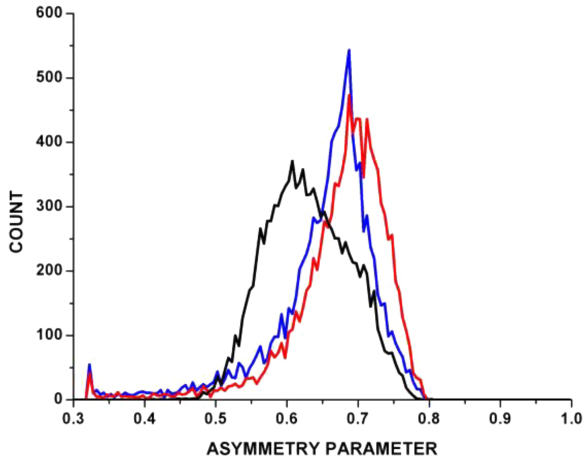

(a)

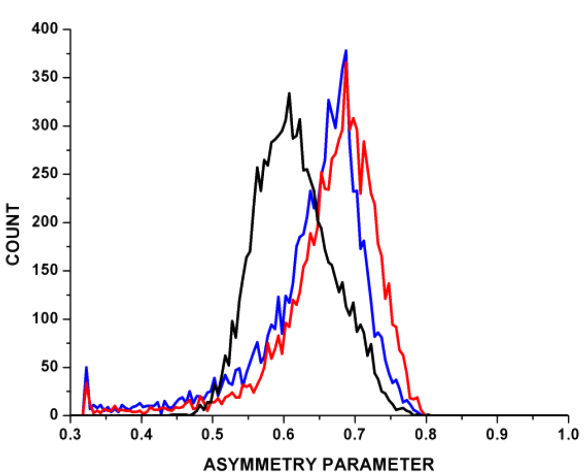

(b)

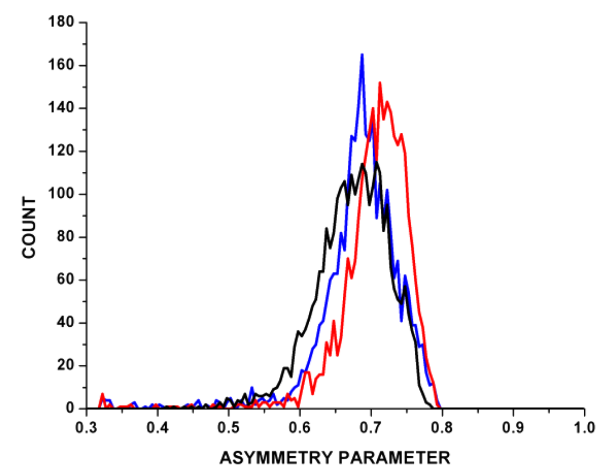

Figure 10. Frequency distribution histograms for MODISTerra (red colored lines) MODIS-Aqua (blue-colored lines) and AERONET (black lines) $g_{\text {aer }}$ values at 860 and $870 \mathrm{~nm}$, respectively. The histograms are given separately for (a) the entire study region, (b) Europe, and (c) Africa, the Middle East and the Arabian Peninsula.

smaller than larger values, i.e., more for fine than coarse particles.

We present the frequency distributions of asymmetry parameter daily values (Fig. 10) on the days when data from all three databases (MODIS-Terra, MODIS-Aqua and AERONET) were provided. Figure 10a corresponds to the whole area of interest, while Fig. 10b and c correspond to two broad sub-regions with basic differences in the aerosol 
Table 1. Correlation coefficients $(R)$, mean bias, root mean squared error (RMSE) and the slope and intercept values of applied linear regression fits between MODIS and AERONET $g_{\text {aer }}$ data. The statistical parameters are given separately for the pairs of wavelengths: (i) $470 \mathrm{~nm}$ (MODIS) and $440 \mathrm{~nm}$ (AERONET), (ii) $660 \mathrm{~nm}$ (MODIS) and $675 \mathrm{~nm}$ (AERONET) and (iii) $860 \mathrm{~nm}$ (MODIS) and $870 \mathrm{~nm}$ (AERONET). The statistical parameters are also given separately for winter, spring, summer and autumn.

\begin{tabular}{|c|c|c|c|c|c|c|}
\hline & & $R^{\mathrm{a}}$ & Bias $^{b}$ & RMSE & Slope & Intercept \\
\hline \multicolumn{7}{|c|}{ MODIS-Terra } \\
\hline \multirow{3}{*}{ Year } & $470-440$ & 0.25 & $2 \times 10^{-4}$ & 0.045 & 0.36 & 0.45 \\
\hline & $660-675$ & 0.41 & -0.028 & 0.060 & 0.55 & 0.32 \\
\hline & $860-870$ & 0.47 & -0.035 & 0.070 & 0.60 & 0.29 \\
\hline \multirow[t]{3}{*}{ Winter } & $470-440$ & 0.20 & $4.5 \times 10^{-4}$ & 0.046 & 0.26 & 0.53 \\
\hline & $660-675$ & 0.35 & -0.033 & 0.056 & 0.41 & 0.42 \\
\hline & $860-870$ & 0.41 & -0.053 & 0.057 & 0.40 & 0.43 \\
\hline \multirow[t]{3}{*}{ Spring } & $470-440$ & 0.27 & $-5 \times 10^{-4}$ & 0.046 & 0.40 & 0.43 \\
\hline & $660-675$ & 0.44 & -0.023 & 0.060 & 0.63 & 0.27 \\
\hline & $860-870$ & 0.50 & -0.026 & 0.071 & 0.67 & 0.24 \\
\hline \multirow[t]{3}{*}{ Summer } & $470-440$ & 0.33 & -0.002 & 0.044 & 0.51 & 0.35 \\
\hline & $660-675$ & 0.48 & -0.031 & 0.061 & 0.71 & 0.22 \\
\hline & $860-870$ & 0.54 & -0.030 & 0.077 & 0.79 & 0.16 \\
\hline \multirow[t]{3}{*}{ Autumn } & $470-440$ & 0.21 & 0.003 & 0.044 & 0.30 & 0.50 \\
\hline & $660-675$ & 0.33 & -0.027 & 0.059 & 0.45 & 0.38 \\
\hline & $860-870$ & 0.41 & -0.035 & 0.068 & 0.53 & 0.34 \\
\hline \multicolumn{7}{|c|}{ MODIS-Aqua } \\
\hline \multirow{3}{*}{ Year } & $470-440$ & 0.27 & 0.018 & 0.047 & 0.41 & 0.40 \\
\hline & $660-675$ & 0.42 & -0.005 & 0.062 & 0.61 & 0.26 \\
\hline & $860-870$ & 0.46 & -0.015 & 0.072 & 0.61 & 0.26 \\
\hline \multirow[t]{3}{*}{ Winter } & $470-440$ & 0.25 & 0.024 & 0.049 & 0.36 & 0.43 \\
\hline & $660-675$ & 0.39 & -0.001 & 0.062 & 0.55 & 0.30 \\
\hline & $860-870$ & 0.43 & -0.021 & 0.068 & 0.51 & 0.33 \\
\hline \multirow[t]{3}{*}{ Spring } & $470-440$ & 0.29 & 0.015 & 0.048 & 0.45 & 0.38 \\
\hline & $660-675$ & 0.45 & -0.003 & 0.064 & 0.70 & 0.20 \\
\hline & $860-870$ & 0.50 & -0.007 & 0.076 & 0.71 & 0.19 \\
\hline \multirow[t]{3}{*}{ Summer } & $470-440$ & 0.35 & 0.014 & 0.045 & 0.55 & 0.30 \\
\hline & $660-675$ & 0.50 & -0.012 & 0.060 & 0.72 & 0.19 \\
\hline & $860-870$ & 0.53 & -0.018 & 0.074 & 0.73 & 0.19 \\
\hline \multirow[t]{3}{*}{ Autumn } & $470-440$ & 0.20 & 0.021 & 0.047 & 0.30 & 0.47 \\
\hline & $660-675$ & 0.32 & -0.003 & 0.061 & 0.46 & 0.36 \\
\hline & $860-870$ & 0.37 & -0.014 & 0.069 & 0.48 & 0.34 \\
\hline
\end{tabular}

source, namely Europe with great anthropogenic sources, and Africa, the Middle East and the Arabian Peninsula, with predominant natural sources and mainly desert dust. There is an apparent skew in the MODIS-Terra and MODIS-Aqua $g_{\text {aer }}$ distributions, while the AERONET distributions are more symmetrical. Moreover, the satellite data distributions show larger values and smaller standard deviations compared to AERONET, with the Terra overestimation being more exaggerated. The disagreement is more pronounced in the sub- region of Europe, while in the sub-region of North Africa/ the Arabian Peninsula, the distributions of satellite and surface data agree more thus confirming the finding of Fig. 9 based on the slope of applied linear regression fit. Values over Europe are generally smaller than over North Africa/ the Arabian Peninsula (Fig. 3), which can be attributed to the presence of larger size particles of desert origin in the latter sub-region, in contrast to Europe, where due to industrial activity and frequent biomass burning the presence of smaller 
size particles is important. Therefore, the smaller $g_{\text {aer }}$ values $(<0.6)$ in the frequency distributions of the whole area, are overwhelmingly contributed by the European sub-region, contrasting with larger values $(0.7-0.75)$ being contributed by both sub-regions and even more by North Africa/ the Arabian Peninsula at larger $g_{\text {aer }}$ values.

The overall comparison between satellite and surface $g_{\text {aer }}$ data performed in the scatterplot of Fig. 9 and Table 1 does not allow one to have an insight to how the comparison behaves spatially, namely how it differs from one region to another. This is addressed in Fig. 11, showing the comparison of satellite and surface data at the wavelength of 860/870 nm separately between MODIS-Terra - AERONET and MODIS-Aqua - AERONET. For this comparison, we selected AERONET stations for which there is satisfactory overlap between the time series from AERONET and the time series from MODIS, namely the number of common days between AERONET-Terra and AERONET-Aqua is larger than 100 . This criterion is satisfied by 36 stations for AERONET-Terra and by 34 for AERONET-Aqua shown in Fig. 11. For each AERONET station we compute the Pearson correlation coefficient between the station data at $870 \mathrm{~nm}$ and the corresponding MODIS-Terra or Aqua data at $860 \mathrm{~nm}$, for the $1^{\circ} \times 1^{\circ}$ cell containing the station. Moreover, there is the information if the trends between AERONET and either MODIS-Terra or Aqua have the same sign (blue color) or not (red color).

In the case of the $g_{\text {aer }}($ AERONET $)-g_{\text {aer }}$ (Terra) comparison, at 5 stations, (i.e., in $14 \%$ of total 36 stations), the correlation coefficient $R$ is larger than 0.5 (largest $R$ found is 0.64 at station "Bahrain"), while at 13 stations (36\%) and 26 stations ( $72 \%) R$ is larger than 0.4 and 0.3 , respectively. With respect to the agreement on the sign of the trends, at 24 out of 36 stations $(67 \%)$ there is a trend sign match and at 12 stations $(33 \%)$ a mismatch. Nevertheless, it should be noted that no systematic spatial behavior, i.e., homogeneous spatial patterns, is found concerning the performance of MODIS-Terra $g_{\text {aer }}$ against AERONET in terms of either the magnitude of correlation or the agreement of trends between the satellite and ground data sets. A similar picture emerges for the comparison $g_{\text {aer }}($ AERONET $)-g_{\text {aer }}($ Aqua $)$. In this case, there are again 5 stations ( $15 \%$ of total 34 stations) with $R>0.5$ (maximum value $R=0.61$ again at "Bahrain"), while at 13 stations ( $38 \%)$ and 24 stations ( $71 \%), R$ is larger than 0.4 and 0.3 , respectively. Also, we see that at 22 stations ( $65 \%)$ there is a trend sign match and at $12(35 \%)$ there is a mismatch.

\section{Summary and conclusions}

Using satellite collection (051) MODIS-Terra and Aqua data, we examine the spatiotemporal variations of the aerosol asymmetry parameter $\left(g_{\text {aer }}\right)$ over North Africa, the Arabian Peninsula and Europe. To our knowledge, this is the first time that a satellite-based (MODIS) data set of $g_{\text {aer }}$, assessed and

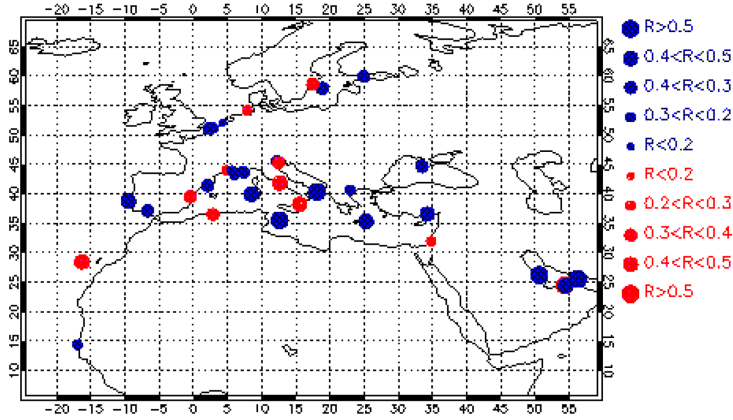

(a)

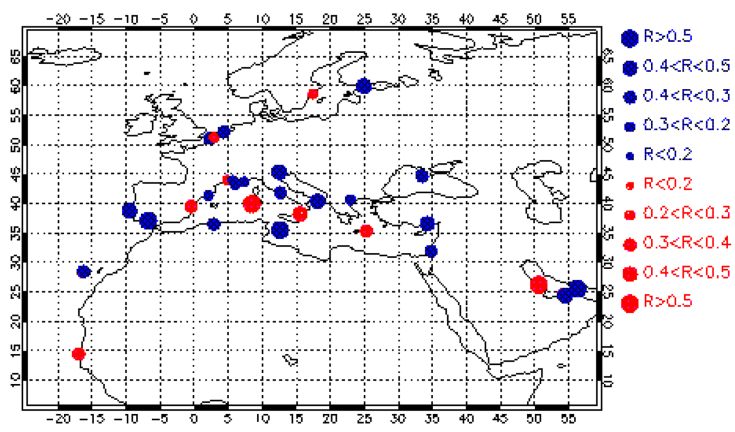

(b)

Figure 11. Map distribution of correlation coefficients between (a) MODIS-Terra and AERONET $g_{\text {aer }}$ values at 860 and $870 \mathrm{~nm}$, respectively (top panel) and (b) MODIS-Aqua and AERONET $g_{\text {aer }}$ values at 860 and $870 \mathrm{~nm}$ (bottom panel). The size of circles corresponds to the magnitude of correlation coefficients, while blue and red colors are used for stations for which MODIS and AERONET indicate same and opposite tendency of $g_{\text {aer }}$, respectively.

evaluated (against AERONET data), is used for the study region. This is important, since such an evaluated satellite data set is very useful for many applications, like radiative transfer and climate modeling as well as for remote sensing. The advantages of MODIS $g_{\text {aer }}$ data are the following.

1. They ensure complete spatial coverage over sea surfaces surrounding Europe, Mediterranean and Middle East, which is essential for investigating and understanding physical processes related to aerosols. These processes are strongly dependent on the aerosol radiative and optical properties, $g_{\text {aer }}$ being one of the three key ones (the other two being aerosol optical thickness and single scattering albedo). Such a complete spatial coverage is especially required by radiative transfer and climate models.

2. They provide spectral $g_{\text {aer }}$ values, at seven wavelengths from 470 to $2130 \mathrm{~nm}$, which are of essential importance for radiative transfer models. Such spectrally resolved aerosol optical properties can induce significant differences in model computations of aerosol radiative effects (Hatzianastassiou et al., 2007). 
3. They provide a relatively long temporal coverage, i.e., 8 years, which is significant for examining seasonal and inter-annual cycles and changes of this aerosol optical property, especially combined with the complete spatial coverage. This is also important since it provides a reasonable statistical bed for attempting evaluations through comparison against other $g_{\text {aer }}$ data like the AERONET.

4. They constitute the first known so far satellite-based $g_{\text {aer }}$ data set; until now, the utilized $g_{\text {aer }}$ data in modeling or other analyses were taken from in situ measurements or aerosol models, which both have their own deficiencies, namely limited spatial coverage or pure theoretical basis, respectively.

According to the obtained results, generally, the largest values of the asymmetry parameter, indicating the strongest forward scattering of radiation by atmospheric aerosols, are found over areas with aerosol load being dominated by large particles of desert dust (tropical Atlantic, Arabian and Red seas). On the contrary, smaller $g_{\text {aer }}$ values are seen where a significant fraction of aerosol load comes from small size particles of anthropogenic origin, e.g., over the Black Sea. The results are consistent with the theory and thus indicate a good performance of the MODIS retrieval of aerosol asymmetry parameter. Depending on the area of interest, the seasonal cycle of the asymmetry parameter varies markedly. More specifically, in areas with abundance of desert dust particles, the range of intra-annual variation is small, with the largest values during summer, while in other areas the seasonality is reversed, with the largest values during the cold season and the smallest during the warm season. The asymmetry parameter decreases with wavelength, especially when one examines its spatially minimum values, while this decrease is weaker for the larger $g_{\text {aer }}$ values, corresponding to the presence of coarser particles.

The seasonal fluctuation is more pronounced with increasing wavelength in the examined regions, which is attributed to the different spectral behavior of the asymmetry parameter for small and large particles. With respect to the interannual variability of the asymmetry parameter, we did not discern very important either increasing or decreasing tendencies, with absolute changes smaller than 0.04 in any case. On the other hand, we found opposing tendencies for the two satellite data sets. MODIS-Terra observes mostly increasing tendencies, while Aqua gives also a few regions with decreasing tendencies. Generally, the largest intra-annual and inter-annual variations are seen over the Black Sea, while the smallest was seen over the tropical Atlantic. However, some strong trends (especially from Terra) may be due to calibration drift errors, which may be addressed in collection 006 . Along these lines, we performed some preliminary comparisons between 051 and 006 Ångström Exponent trends from Aqua, which ensured that $\mathrm{AE}$ and $g_{\text {aer }}$ are very closely anticorrelated. These preliminary results, show that 051 Aqua
$\mathrm{AE}$ trends resemble very closely the 006 trends, supporting that the $g_{\text {aer }}$ trends from collection 051 (at least for Aqua) reported in this study are credible.

The 051 MODIS $g_{\text {aer }}$ data is not a retrieved but a derived MODIS parameter. Given that the retrieval is strongly dependent on the assumptions made, namely on the aerosol modes used, uncertainties can be associated with its use in radiative transfer modeling. In order to examine these uncertainties, the $g_{\text {aer }}$ data were compared with $051 \mathrm{AE}$ data for the same period. The results from the comparison showed a strong anti-correlation (coefficient higher than $0.7-0.8$ ) proving the consistency and reasonably safe use of $g_{\text {aer }}$ data in modeling studies, at least to the same degree with MODIS $\mathrm{AE}$ data in modeling and other analyses. The correlation is even higher over sea areas characterized by stronger presence of fine aerosols, like the Black Sea, the Persian Gulf or the North Sea. This confidence is further strengthened by the small identified uncertainties related with the use of collection 051 instead of 006 MODIS $g_{\text {aer }}$ data reported in the previous paragraph. This was obtained indirectly based on the use of AE data of both collections since $g_{\text {aer }}$ data are not yet available in collection 006 .

We compare satellite data with surface data from the AERONET, in order to further validate the reliability of the former. Through the examination of frequency distributions of daily $g_{\text {aer }}$, a shift of satellite data towards larger values relative to surface data becomes apparent. This finding is more pronounced for $g_{\text {aer }}$ over Europe, while the North African and Arabian Peninsula values are more in agreement. Moreover, the smallest $g_{\text {aer }}$ values originate from particles from Europe, because of the generation of smaller size particles by industrial activities and biomass burning.

We present scatter plots of daily $g_{\text {aer }}$ values between MODIS-Terra, MODIS-Aqua, and AERONET, which show moderate agreement between satellite data at $470 \mathrm{~nm}$ and surface data at $440 \mathrm{~nm}$, with small correlation coefficients $(R<0.3)$ and a slight underestimation by MODIS. Slightly better agreement was noted at larger wavelengths, but still without reaching very satisfactory levels $(R<0.47)$. Nevertheless, during spring and summer, satellite and surface measurements tend to agree more. Finally, for the comparisons at $660 / 675$ and $860 / 870 \mathrm{~nm}$, we report an overestimation of $g_{\text {aer }}$ by MODIS compared to AERONET.

When examined at the local scale, i.e., station by station, the MODIS $g_{\text {aer }}$ data agree reasonably and for some stations better than in overall, but still not very well, with those of AERONET. This analysis, based on 36 and 34 AERONET stations ensuring at least 100 common days with MODISTerra and Aqua, respectively, shows that in 36 and $38 \%$ of stations, respectively, the MODIS data have correlation coefficients larger than 0.4 (reaching values up to 0.64), while in about $65 \%$ of stations the trends of $g_{\text {aer }}$ from MODIS and AERONET have the same sign. Nevertheless, the magnitude of correlation coefficients or the agreement between trends 
of $g_{\text {aer }}$ from the satellite and ground data sets do not exhibit a systematic (homogeneous) spatial pattern.

Our results offer an interesting way to assess the uncertainty induced by the use of such satellite $g_{\text {aer }}$ data in climate and radiative transfer models that compute aerosol radiative and climate effects. Based on an overall assessment of satellite MODIS $g_{\text {aer }}$ through detailed comparisons against ground AERONET data, it appears that in overall MODIS performs satisfactorily in terms of magnitude of $g_{\text {aer }}$ values. This is indicated by the computed biases, which are smaller than $5 \%$ with respect to MODIS values, with better performance at smaller wavelengths. The root mean squared errors vary within the range 5-10\% again being smaller for smaller wavelengths. These results indicate an uncertainty of MODIS $g_{\text {aer }}$ data over the study region up to of $10 \%$ at maximum. Previous analyses and sensitivity studies for the same study region (Papadimas et al., 2012) have shown that such $g_{\text {aer }}$ uncertainties can induce modifications of aerosol direct radiative effects (DREs) which are equal to $30 \%$ at the topof-atmosphere (TOA) and $1 \%$ in the atmosphere and $10 \%$ at the surface, at maximum. Therefore, the uncertainty associated with the use of MODIS $g_{\text {aer }}$ is larger than any aerosol related physical process taking place at TOA, namely planetary cooling or warming and its magnitude, smaller for processes at the Earth's surface, e.g., surface cooling and very small for aerosol processes and feedbacks in the atmosphere, like the aerosol semi-direct effect and its implications. Results from the same previous analysis (Papadimas et al., 2012) proved that the exact magnitude of MODIS $g_{\text {aer }}$ DRE uncertainty can be estimated by simple linear equations relating DREs and $g_{\text {aer }}$, separately given for TOA, atmosphere and surface.

The results of the present analysis are useful since they assess for the first time the performance of satellite-based products of aerosol asymmetry parameter over broad regions of special climatic interest. The obtained results are relatively satisfactory given the difficulties encountered by satellite retrieval algorithms due to the different assumptions they made. Nevertheless, our results and identified weaknesses remind that users should be aware of the $g_{\text {aer }}$ uncertainties and their consequences. The identified weaknesses may provide an opportunity to improve such satellite retrievals of aerosol asymmetry parameter in forthcoming data products like those of MODIS C006. The increased temporal coverage of $g_{\text {aer }}$ data, combined with the continued operation of MODIS, is expected to make possible the building of the first real satellite climatology of this important aerosol optical property.

Acknowledgements. This research has been co-financed by the European Union (European Social Fund - ESF) and Greek national funds through the operational program "Education and Lifelong Learning" of the National Strategic Reference Framework (NSRF) - Research Funding Program: THALES. Investing in knowledge society through the European Social Fund. The Collection 051 MODIS-Terra data were obtained from NASA's Level 1 and
Atmosphere Archive and Distribution System (LAADS) website (ftp://ladsweb.nascom.nasa.gov/). We would like to thank the principal investigators maintaining the AERONET sites used in the present work. We would also like to thank three anonymous Reviewers and Dr Kaskaoutis for helping to improve the manuscript with their comments.

Edited by: A. Nenes

\section{References}

Alonso-Pérez, S., Cuevas, E., Querol, X., Guerra, J. C., and Pérez C.: African dust source regions for observed dust outbreaks over the Subtropical Eastern North Atlantic region, above $25^{\circ} \mathrm{N}, \mathrm{J}$. Arid Environ., 79, 100-109, doi:10.1016/j.jaridenv.2011.11.013, 2012.

Barnaba, F. and Gobbi, G. P.: Aerosol seasonal variability over the Mediterranean region and relative impact of maritime, continental and Saharan dust particles over the basin from MODIS data in the year 2001, Atmos. Chem. Phys., 4, 2367-2391, doi:10.5194/acp-4-2367-2004, 2004.

Barnaba, F., Angelini, F., Curci, G., and Gobbi, G. P.: An important fingerprint of wildfires on the European aerosol load, Atmos. Chem. Phys., 11, 10487-10501, doi:10.5194/acp-1110487-2011, 2011.

Bovchaliuk, A., Milinevsky, G., Danylevsky, V., Goloub, P., Dubovik, O., Holdak, A., Ducos, F., and Sosonkin, M.: Variability of aerosol properties over Eastern Europe observed from ground and satellites in the period from 2003 to 2011, Atmos. Chem. Phys., 13, 6587-6602, doi:10.5194/acp-13-6587-2013, 2013.

Bréon, F.-M., Vermeulen, A., and Descloitres, J.: An evaluation of satellite aerosol products against sunphotometers measurements, Remote Sens. Environ., 115, 3102-3111, 2011.

Chubarova, N. Y.: Seasonal distribution of aerosol properties over Europe and their impact on UV irradiance, Atmos. Meas. Tech., 2, 593-608, doi:10.5194/amt-2-593-2009, 2009.

Di Iorio, T., di Sarra, A., Junkermann, W., Cacciani, M., Fiocco, G., and Fua, D.: Tropospheric aerosols in the Mediterranean: 1. Microphysical and optical properties, J. Geophys. Res., 108, 4316, doi:10.1029/2002JD002815, 2003.

Dubovik, O. and King, M. D.: A flexible inversion algorithm for retrieval of aerosol optical properties from Sun and sky radiance measurements, J. Geophys. Res., 105, 20673-20696, 2000.

Dubovik, O., Holben, B., Eck, T. F., Smirnov, A., Kaufman, Y. J., King, M. D., Tanré, D., Slutsker, I.: Variability of Absorption and Optical Properties of Key Aerosol Types Observed in Worldwide Locations, J. Atmos. Sci., 59, 590-608, 2002.

Engelstaedter, S., Tegen, I., and Washington, R.: North African dust emissions and transport, Earth-Sci. Revi., 79, 73-100, 2006.

Fotiadi, A., Hatzianastassiou, N., Drakakis, E., Matsoukas, C., Pavlakis, K. G., Hatzidimitriou, D., Gerasopoulos, E., Mihalopoulos, N., and Vardavas, I.: Aerosol physical and optical properties in the Eastern Mediterranean Basin, Crete, from Aerosol Robotic Network data, Atmos. Chem. Phys., 6, 53995413, doi:10.5194/acp-6-5399-2006, 2006.

Gerasopoulos, E., Kouvarakis, G., Babasakalis, P., Vrekoussis, M., Putaud, J. P., and Mihalopoulos, N.: Origin and variability of 
particulate matter $\left(\mathrm{PM}_{10}\right)$ mass concentrations over the Eastern Mediterranean, Atmos. Environ., 40, 4679-4690, 2006.

Ginoux, P., Prospero, J. M., Gill, T. E., Hsu, C. N., and Zhao, M.: Global-scale attribution of anthropogenic and natural dust sources and their emission rates based on MODIS Deep Blue aerosol products, Rev. Geophys., 50, RG3005, doi:10.1029/2012RG000388, 2012.

Gkikas, A., Hatzianastassiou, N., and Mihalopoulos, N.: Aerosol events in the broader Mediterranean basin based on 7-year (2000-2007) MODIS C005 data, Ann. Geophys., 27, 35093522, doi:10.5194/angeo-27-3509-2009, 2009.

Gkikas, A., Houssos, E., Hatzianastassiou, N., Papadimas, C., and Bartzokas, A.: Synoptic conditions favouring the occurrence of aerosol episodes over the broader Mediterranean basin, Q. J. Roy. Meteorol. Soc., doi:10.1002/qj.978, 2011.

Gkikas, A., Hatzianastassiou, N., Mihalopoulos, N., Katsoulis, V., Kazadzis, S., Pey, J., Querol, X., and Torres, O.: The regime of intense desert dust episodes in the Mediterranean based on contemporary satellite observations and ground measurements, Atmos. Chem. Phys., 13, 12135-12154, doi:10.5194/acp-1312135-2013, 2013.

Gkikas, A., Houssos, E. E., Lolis, C. J., Bartzokas, A., Mihalopoulos, N., and Hatzianastassiou, N.: Atmospheric circulation evolution related to desert-dust episodes over the Mediterranean, Q. J. Roy. Meteorol. Soc., 690, 1634-1645, 2014.

Goloub, P. and Arino, O.: Verification of the consistency of POLDER aerosol index over land with ATSR-2 fire product, Geophys. Res. Lett., 27, 899-902, 2000.

Graß1, H.: Possible changes of planetary albedo due to aerosol particles, in: Man's Impact on Climate, edited by: Bach, W., Pankrath, J., and Kellogg, W., Elsevier, New York, 229-241, 1979.

Hansen, J., Sato, M., and Ruedy, R.: Radiative forcing and climate response, J. Geophys. Res., 102, 6831-6864, 1997.

Hatzianastassiou, N., Katsoulis, B., and Vardavas, I.: Sensitivity analysis of aerosol direct radiative forcing in ultraviolet - visible wavelengths and consequences for the heat budget, Tellus, 56b, 368-381, 2004.

Hatzianastassiou, N., Matsoukas, C., Drakakis, E., Stackhouse Jr., P. W., Koepke, P., Fotiadi, A., Pavlakis, K. G., and Vardavas, I.: The direct effect of aerosols on solar radiation based on satellite observations, reanalysis datasets, and spectral aerosol optical properties from Global Aerosol Data Set (GADS), Atmos. Chem. Phys., 7, 2585-2599, doi:10.5194/acp-7-2585-2007, 2007.

Hatzianastassiou, N., Gkikas, A., Mihalopoulos, N., Torres, O., and Katsoulis, B. D.: Natural versus anthropogenic aerosols in the eastern Mediterranean basin derived from multiyear TOMS and MODIS satellite data, J. Geophys. Res., 114, D24202, doi:10.1029/2009JD011982, 2009.

Holben, B. N., Eck, T. F., Slutsker, I., Tanré, D., Buis, J. P., Setzer, A., Vermote, E., Reagan, J. A., Kaufman, Y., Nakajima, T., Lavenu, F., Jankowiak, I., and Smirnov, A.: AERONET - A federated instrument network and data archive for aerosol characterization, Rem. Sens. Environ., 66, 1-16, 1998.

Ichoku, C., Chu, D. A., Mattoo, S., Kaufman, Y. J., Remer, L. A., Tanré, D., Slutsker, I., and Holben, B. N.: A spatiotemporal approach for global validation and analysis of MODIS aerosol products, Geophys. Res. Lett., 29, MOD1-1-MOD1-4, doi:10.1029/2001GL013206, 2002.
IPCC: Climate Change 2007: The Physical Science Basis. Contribution of Working Group I to the Fourth Assessment Report of the Intergovernmental Panel on Climate Change, edited by: Solomon, S., Qin, D., Manning, M., Chen, Z., Marquis, M., Averyt, K. B.,Tignor, M., and Miller, H. L., Cambridge University Press, Cambridge, UK and New York, NY, USA, 996 pp., 2007.

IPCC: Climate Change 2013: The Physical Science Basis. Contribution of Working Group I to the Fifth Assessment Report of the Intergovernmental Panel on Climate Change, edited by: Stocker, T. F., Qin, D., Plattner, G.-K., Tignor, M., Allen, S. K., Boschung, J., Nauels, A., Xia, Y., Bex, V., and Midgley, P. M., Cambridge University Press, Cambridge, United Kingdom and New York, NY, USA, 1535 pp., 2013.

Jianrong, B., Huang, J., Fu, Q., Wanga, X., Shi, J., Zhang, W., Huang, Z., Zhang, B.: Toward characterization of the aerosol optical properties over Loess Plateau of Northwestern China, J. Quant. Spectrosc. Ra., 112, 346-360, 2011.

Joseph, J. H., Wiscombe, W. J., and Weinman, J. A.: The deltaEddington approximation for radiative flux transfer, J. Atmos. Sci., 33, 2452-2459, 1976.

Kalapureddy, M. C. R., Kaskaoutis, D. G., Ernest Raj, P., Devara, P. C. S., Kambezidis, H. D., Kosmopoulos, P. G., and Nastos, P. T.: Identification of aerosol type over the Arabian Sea in the premonsoon season during the Integrated Campaign for Aerosols, Gases and Radiation Budget (ICARB), J. Geophys. Res., 114, D17203, doi:10.1029/2009JD011826, 2009.

Kalivitis, N., Gerasopoulos, E., Vrekoussis, M., Kouvarakis, G., Kubilay, N., Hatzianastassiou, N., Vardavas, I., and Mihalopoulos, N.: Dust transport over the eastern Mediterranean derived from TOMS, AERONET and surface measurements, J. Geophys. Res., 112, D03202, doi:10.1029/2006JD007510, 2007.

Kaufman, Y. J., Tanré, D., Remer, L. A., Vermote, E. F., Chu, A., and Holben, B. N.: Operational remote sensing of tropospheric aerosol over land from EOS moderate resolution imaging spectroradiometer, J. Geophys. Res., 102, 17051-17067, 1997.

Kinne, S., O’Donnel, D., Stier, P., Kloster, S., Zhang, K., Schmidt, H., Rast, S., Giorgetta, M., Eck, T. F., and Stevens, B.: MACv1: A new global aerosol climatology for climate studies, J. Adv. Model. Earth Syst., 5, 704-740, doi:10.1002/jame.20035, 2013.

Kishcha, P., da Silva, A. M., Starobinets, B., Long, C. N., Kalashnikova, O., and Alpert, P.: Meridional distribution of aerosol optical thickness over the tropical Atlantic Ocean, Atmos. Chem. Phys. Discuss., 14, 23309-23339, doi:10.5194/acpd-14-233092014, 2014.

Koepke, P., Hess, M., Schult, I., and Shettle, E. P.: Global aerosol data set, Rep. No. 243, Max-Planck Institut für Meteorologie, Hamburg, Germany, 44 pp., 1997.

Kondratyev, K. Y.: Climatic effects of aerosols and clouds, Springer, New York, 264 pp., 1999.

Kutiel, H. and Furman, H.: Dust storms in the Middle East: sources of origin and their temporal characteristics, Indoor Built Environ., 12, 419-426, 2003.

Lelieveld, J., Berresheim, H., Borrmann, S., Crutzen, P. J., Dentener, F. J., Fischer, H., Feichter, J., Flatau, P. J., Heland, J., Holzinger, R., Korrmann, R., Lawrence, M. G., Levin, Z., Markowicz, K. M., Mihalopoulos, N., Minikin, A., Ramanathan, V., de Reus, M., Roelofs, G. J., Scheeren, H. A., Sciare, J., Schlager, H., Schultz, M., Siegmund, P., Steil, B., Stephanou, E. G., Stier, P., Traub, M., Warneke, C., Williams, J., and Ziereis, 
H.: Global air pollution crossroads over the Mediterranean, Science, 298, 794-799, doi:10.1126/science.1075457, 2002.

Levy, R. C., Remer, L. A., Kleidman, R. G., Mattoo, S., Ichoku, C., Kahn, R., and Eck, T. F.: Global evaluation of the Collection 5 MODIS dark-target aerosol products over land, Atmos. Chem. Phys., 10, 10399-10420, doi:10.5194/acp-10-10399-2010, 2010.

Levy, R. C., Mattoo, S., Munchak, L. A., Remer, L. A., Sayer, A. M., Patadia, F., and Hsu, N. C.: The Collection 6 MODIS aerosol products over land and ocean, Atmos. Meas. Tech., 6, 29893034, doi:10.5194/amt-6-2989-2013, 2013.

Liou, K. N: An introduction to atmospheric radiation, International Geophysics Series, 84, Academic Press, New York, 2002.

Lohmann, U. and Feichter, J.: Global indirect aerosol effects: a review, Atmos. Chem. Phys., 5, 715-737, doi:10.5194/acp-5-7152005, 2005.

Lyamani, H., Olmo, F. J., Alcántara, A., and Alados-Arboledas, L.: Atmospheric aerosols during the 2003 heat wave in southeastern Spain. I: Spectral optical depth, Atmos. Environ., 40, 6453-6464, doi:10.1016/j.atmosenv.2006.04.048, 2006.

Lyapustin, A., Wang, Y., Xiong, X., Meister, G., Platnick, S., Levy, R., Franz, B., Korkin, S., Hilker, T., Tucker, J., Hall, F., Sellers, P., Wu, A., and Angal, A.: Scientific impact of MODIS C5 calibration degradation and C6+ improvements, Atmos. Meas. Tech., 7, 4353-4365, doi:10.5194/amt-7-4353-2014, 2014.

Miller, S. D., Kuciauskas, A. P., Liu, M., Ji, Q., Reid, J. S., Breed, D. W., Walker, A. L., and Mandoos, A. A.: Haboob dust storms of the southern Arabian Peninsula, J. Geophys. Res., 113, D01202, doi:10.1029/2007JD008550, 2008.

Nabat, P., Somot, S., Mallet, M., Chiapello, I., Morcrette, J. J., Solmon, F., Szopa, S., Dulac, F., Collins, W., Ghan, S., Horowitz, L. W., Lamarque, J. F., Lee, Y. H., Naik, V., Nagashima, T., Shindell, D., and Skeie, R.: A 4-D climatology (1979-2009) of the monthly tropospheric aerosol optical depth distribution over the Mediterranean region from a comparative evaluation and blending of remote sensing and model products, Atmos. Meas. Tech., 6, 1287-1314, doi:10.5194/amt-6-1287-2013, 2013.

Papadimas, C. D., Hatzianastassiou, N., Mihalopoulos, N., Querol, X., and Vardavas, I.: Spatial and temporal variability in aerosol properties over the Mediterranean basin based on 6year (2000-2006) MODIS data, J. Geophys. Res., 113, D11205, doi:10.1029/2007JD009189, 2008.

Papadimas, C. D., Hatzianastassiou, N., Matsoukas, C., Kanakidou, M., Papadimas, C. D., Hatzianastassiou, N., Matsoukas, C., Kanakidou, M., Mihalopoulos, N., and Vardavas, I.: The direct effect of aerosols on solar radiation over the broader Mediterranean basin, Atmos. Chem. Phys., 12, 7165-85, doi:10.5194/acp-12-7165-2012, 2012.

Pace, G., di Sarra, A., Meloni, D., Piacentino, S., and Chamard, P.: Aerosol optical properties at Lampedusa (Central Mediterranean). 1. Influence of transport and identification of different aerosol types, Atmos. Chem. Phys., 6, 697-713, doi:10.5194/acp-6-697-2006, 2006.

Pilinis, Ch., Pandis, S. N., and Seinfeld, J. H.: Sensitivity of direct climate forcing by anthropogenic aerosols to aerosol size distribution and composition, J. Geophys. Res., 100, 18739-18754, 1996.

Prospero, J., Ginoux, P., Torres, O., and Nicholson, S. E.: Environmental Characterization of Global sources of atmospheric soil dust derived from the NIMBUS-7 TOMS absorbing aerosol product, Rev. Geophys., 40, 1002, doi:10.1029/2000RG000095, 2002.

Rahul, P. R. C., Salvekar, P. S., and Devara, P. C. S.: Aerosol optical depth variability over Arabian Sea during drought and normal years of Indian monsoon, Geophys. Res. Lett., 35, 22, doi:10.1029/2008GL035573, 2008.

Rashki, A., Kaskaoutis, D. G., de Rautenbach, C. J. W., Eriksson, P. G., Qiang, M., and Gupta, P.: Dust storms and their horizontal dust loading in the Sistan region, Iran. Aeolian Res., 5, 51-62, 2012.

Rashki, A., Kaskaoutis, D. G., Eriksson, P. G., de W. Rautenbach, C. J., Flamant, C., Abdi Vishkaee, F.: Spatio-temporal variability of dust aerosols over the Sistan region in Iran based on satellite observations, Nat. Hazards, doi:10.1007/s11069-013-0927-0, 2014.

Remer, L. A., Kaufman, Y. J., Tanré, D., Mattoo, S., Chu, D. A., Martins, J. V., Li, R.-R., Ichoku, C., Levy, R. C., Kleidman, R. G., Eck, T. F., Vermote, E., and Holben, B. N.: The MODIS aerosol algorithm, products, and validation, J. Atmos. Sci., 62, 947-973, 2005.

Remer, L. A., Tanre, D., Kaufman, Y. J., Levy, R., and Matoo, S.: Algorithm for Remote Sensing of Tropospheric Aerosol from MODIS: Collection 005, available at: http://modis.gsfc.nasa. gov/data/atbd/atbd_mod02.pdf (last access: 13 November 2015), 2006.

Remer, L. A., Kleidman, R. G., Levy, R. C., Kaufman, Y. J., Tanré, D., Mattoo, S., Martins, J. V., Ichoku, C., Koren, I., Yu, H., and Holben, B. N.: Global aerosol climatology from the MODIS satellite sensors, J. Geophys. Res., 113, D14S07, doi:10.1029/2007JD009661, 2008.

Satheesh, S. K., Ramanathan, V., Li-Jones, X., Lobert, J. M., Podgorny, I. A., Prospero, J. M., Holben, B. N., and Loeb, N. G.: A model for the natural and anthropogenic aerosols over the tropical Indian Ocean derived from Indian Ocean Experiment data, J. Geophys. Res., 104, 27421-27440, 1999.

Satheesh, S. K., Krishna Moorthy, K., Kaufman, Y. J., and Takemura, T.: Aerosol optical depth, physical properties and radiative forcing over the Arabian Sea, Meteorol. Atmos. Phys., 91, 4562,2006

Savoie, D. L., Prospero, J. M., and Nees, R. T.: Nitrate, nonsea-salt sulfate, and mineral aerosolover the northwestern Indian Ocean, J. Geophys. Res., 92, 933-942, 1987.

Sciare, J., Bardouki, H., Moulin, C., and Mihalopoulos, N.: Aerosol sources and their contribution to the chemical composition of aerosols in the Eastern Mediterranean Sea during summertime, Atmos. Chem. Phys., 3, 291-302, doi:10.5194/acp-3-291-2003, 2003.

Smirnov, A., Holben, B. N., Dubovik, O., O’Neill, N. T., Eck, T. F., Westphal, D. L., Goroch, A. K., Pietras, C., and Slutsker, I.: Atmospheric aerosol optical properties in the Persian Gulf, J. Atmos. Sci., 59, 620-634, 2002a.

Smirnov, A., Holben, B. N., Kaufman, Y. J., Dubovik, O., Eck, T. F., Slutsker, I., Pietras, C., and Halthore, R. N.: Optical properties of atmospheric aerosol in maritime environments, J. Atmos. Sci., 59, 501-523, 2002b.

Tanré, D., Kaufman, Y. J., Herman, M., and Mattoo, S.: Remote sensing of aerosol properties over oceans using the MODIS/EOS spectral radiances, J. Geophys. Res., 102, 16971-16988, 1997. 
Tindale, N. W. and Pease, P. P.: Aerosols over the Arabian Sea: Atmospheric transport pathways and concentrations of dust and sea salt, Deep Sea Res., 46, 1577-1595, 1999.

Yu, H., Dickinson, R. E., Chin, M., Kaufman, Y. J., Holben, B. N., Geogdzhayev, I. V., and Mishchenko, M. I.: Annual cycle of global distributions of aerosol optical depth from integration of MODIS retrievals and GOCART model simulations, J. Geophys. Res., 108, 4128, doi:10.1029/2002JD002717, 2003.
Zdun, A., Rozwadowska, A., and Kratzer, S.: Seasonal variability in the optical properties of Baltic aerosols, Oceanologia, 53, 7-34, 2011.

Zuluaga, M. D., Webster, P. J., and Hoyos, C. D.: Variability of aerosols in the tropical Atlantic Ocean relative to African Easterly Waves and their relationship with atmospheric and oceanic environments, J. Geophys. Res., 117, D16207, doi:10.1029/2011JD017181, 2012. 